\title{
1 A combined geomorphological and geophysical approach to characterising \\ 2 relict landslide hazard on the Jurassic Escarpments of Great Britain
}

3

4 David P. Boon ${ }^{\mathrm{a},{ }^{*}}$, Jon E. Chambers ${ }^{\mathrm{b}}$, Peter R. N. Hobbs ${ }^{\mathrm{b}}$, Mathew Kirkham ${ }^{\mathrm{b}}$, Andrew J Merritt ${ }^{\mathrm{c}}$, Claire

5 Dashwood $^{\mathrm{b}}$, Catherine Pennington ${ }^{\mathrm{b}}$, Philip R. Wilby ${ }^{\mathrm{b}}$

7

8

9

10

11

12

14 Abstract

${ }^{\text {a } B r i t i s h ~ G e o l o g i c a l ~ S u r v e y, ~ C o l u m b u s ~ H o u s e, ~ T o n g w y n l a i s, ~ C a r d i f f, ~ C F 15 ~ 7 N E, ~ U K . ~}$

${ }^{\mathrm{b}}$ British Geological Survey, Environmental Science Centre, Keyworth, Nottingham, NG12 5GG, UK

${ }^{\mathrm{c}}$ Plymouth University, Drake Circus, Plymouth, PL4 8AA, UK

*Corresponding author. Tel: +44 2920521962

E-mail address: dboon@bgs.ac.uk (D.P. Boon)

The Jurassic Escarpment in the North York Moors in Northern Britain has a high density of deepseated relict landslides but their regional hazard is poorly understood due to a lack of detailed case studies. Investigation of a typical relict landslide at Great Fryup Dale suggests the crop of the Whitby Mudstone Formation is highly susceptible to landslide hazards. The mudstone lithologies along the Escarpment form large multiple rotational failures which break down at an accelerated rate during wetter climates and degrade into extensive frontal mudflows.

\section{Geomorphological mapping, high resolution LiDAR imagery, boreholes, and geophysical ERT} surveys are deployed in a combined approach to delimit internal architecture of the landslide. Cross sections developed from these data indicate the main movement displaced a bedrock volume of $\mathrm{c}$. $1 \times 10^{7} \mathrm{~m}^{3}$ with a maximum depth of rupture of c. $50 \mathrm{~m}$. The mode of failure is strongly controlled by lithology, bedding, joint pattern, and rate of lateral unloading. Dating of buried peats using the AMS 
method suggests the $10 \mathrm{~m}$ thick frontal mudflow complex was last active in the Late Holocene, after c. $2270 \pm 30$ calendar years BP.

Geomorphic mapping and dating work indicates the landslide is dormant, but slope stability modelling suggests the slope is less stable than previously assumed; implying that this and other similar landslides in Britain may become more susceptible to reactivation or extension during future wetter climatic phases. This study shows the value of a multi-technique approach for landslide hazard assessment and to enhance national landslide inventories.

\section{Keywords: Jurassic Mudstone; Landslide; LiDAR; ERT.}

\section{Introduction}

Landslide hazards pose a threat to people and infrastructure worldwide. They are a constraint on land use and can impact on the economy of an affected community (e.g. Jones and Lee, 1994; Schuster and Highland, 2001). However, our ability to assess hazard and risk in slide prone terrain, such as the North York Moors (NYM) region of the UK, and in Polar Regions currently undergoing deglaciation, is hindered by a lack of knowledge about the magnitude and frequency of events and hillslope processes operating in these settings more generally. This paper provides a baseline reference study for landslide hazards in mudrocks that can be used to calibrate magnitude/frequency estimations for landslide hazard assessments in the region and in similar geological terrain elsewhere. Jurassic mudrocks underlie much of the UK including the North Yorkshire Moors area. These rocks are exposed in coastal slopes which are prone to instability (Jones and Lee, 1994; Fish et al., 2006; Cooper, 2007; Johnson and Fish, 2012) but landslide problems on inland escapement slopes in the NYM region are under-represented in the literature (Senior and Rose, 1994; Waltham and Foster, 
1999; Marsay, 2010; Merritt et al., 2013). Previous geomorphological studies in the region (Fox-

51 Strangways et al., 1885; Gregory, 1962a) did not describe the landslide geology or geomorphology in any great detail. This paper aims to address this knowledge gap.

The study focuses on the Mark Nab landslide in Great Fryup Dale, Upper Eskdale (Fig. 1), which is the largest in a cluster of bedrock landslides distributed throughout several of the deep valleys in the north of the region. We combine newly acquired remote-sensing data (LiDAR), ground-based geomorphological mapping, electrical resistivity tomography (ERT), and geotechnical data into a ground model in order to conceptualise the 3D landslide architecture. We also use Accelerator Mass Spectrometry (AMS) dating methods to further develop the movement history. This ground model was then used to develop a deterministic slope stability model to test theories about trigger and preparatory factors that led to the initial failure; including changes in stress and porewater pressure brought about by glacial erosion, glacial de-buttressing, changes in regional groundwater levels and glacial lake development. An assessment of the present stability state of the dormant slope is also presented to provide an indication of the current and future regional hazard posed by relict landslide systems.

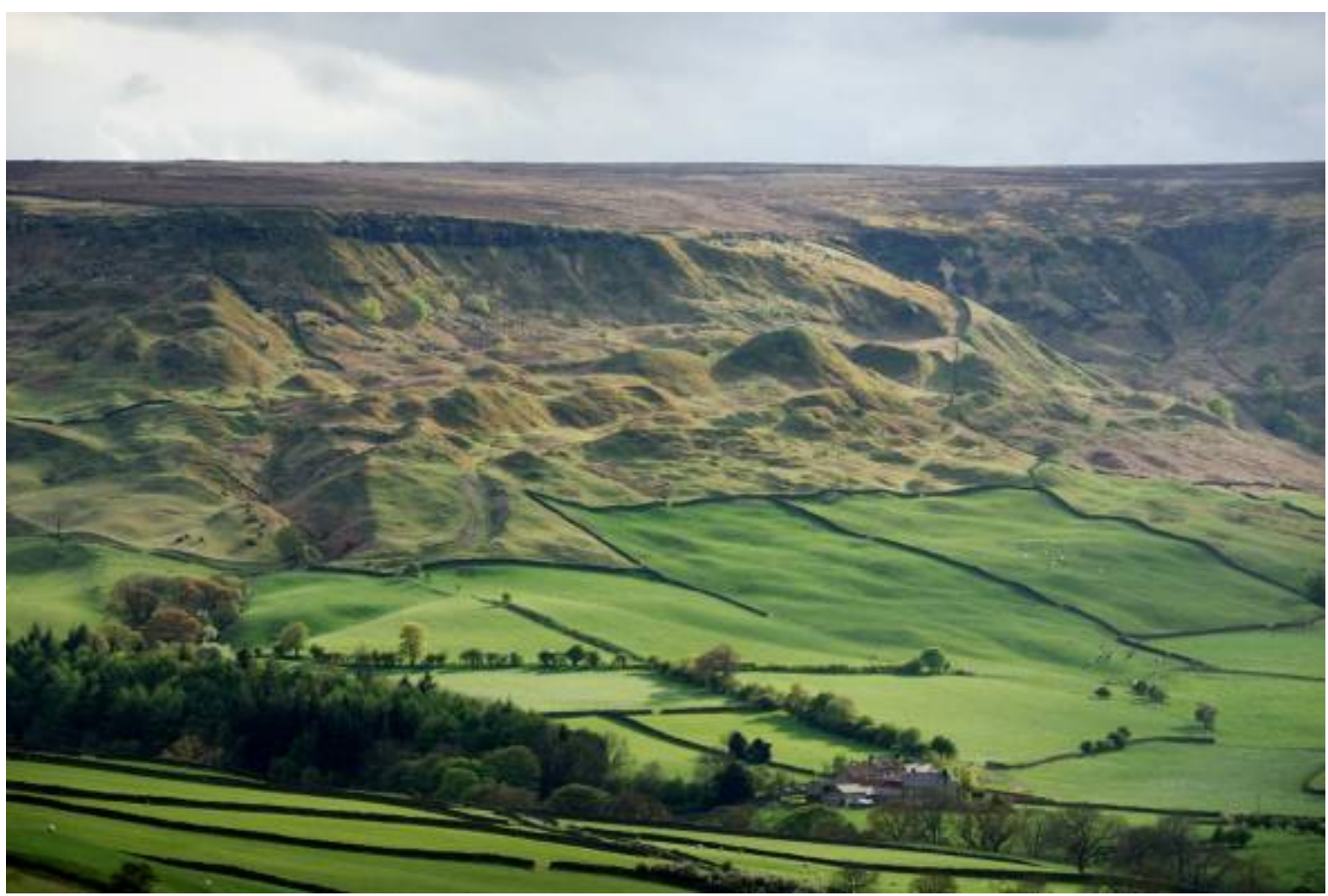


Fig. 1. The Mark Nab landslide on the Jurassic escapement, showing complex landslide morphology.

\section{2. Mark Nab study area}

\subsection{Topography}

The study area, located at British National Grid reference 471350, 502840 (54.42, -0.90 WGS84), covers a north facing slope on the Jurassic escarpment at the head of Great Fryup Dale (Fig. 2). The foot of the slope lies at c. $150 \mathrm{~m}$ above Ordnance Datum (aOD) and rises up over hummocky ground by c. $200 \mathrm{~m}$ over a distance of c. $600 \mathrm{~m}$. At the top of the slope, Middle Jurassic bedrock is exposed in the near-vertical cliff that forms the main Jurassic escarpment, above which is an upland moorland plateau which reaches a high point of $432 \mathrm{~m}$ aOD on Danby High Moor. The plateau sits at the northern edge of the North York Moors which are fragmented by a series of deep valleys generally orientated south-west north-east. The heads of these valleys are commonly incised by streams fed by runoff from peat covered moorland catchments. Numerous springs issue groundwater along the foot of the escarpment. The streams, such as Great Fryup Beck in 'Dale Head' and Slidney Beck (Fig. 2) then flow north-eastwards into the River Esk which discharges into the North Sea at Whitby. At Great Fryup Dale the lower valley slopes are U-shaped and are typically inclined at c. $20^{\circ}$, but towards the

84 head of the valley (Dale Head) the profile becomes increasingly V-shaped and irregular, due to

85 Holocene fluvial incision and slippage. 


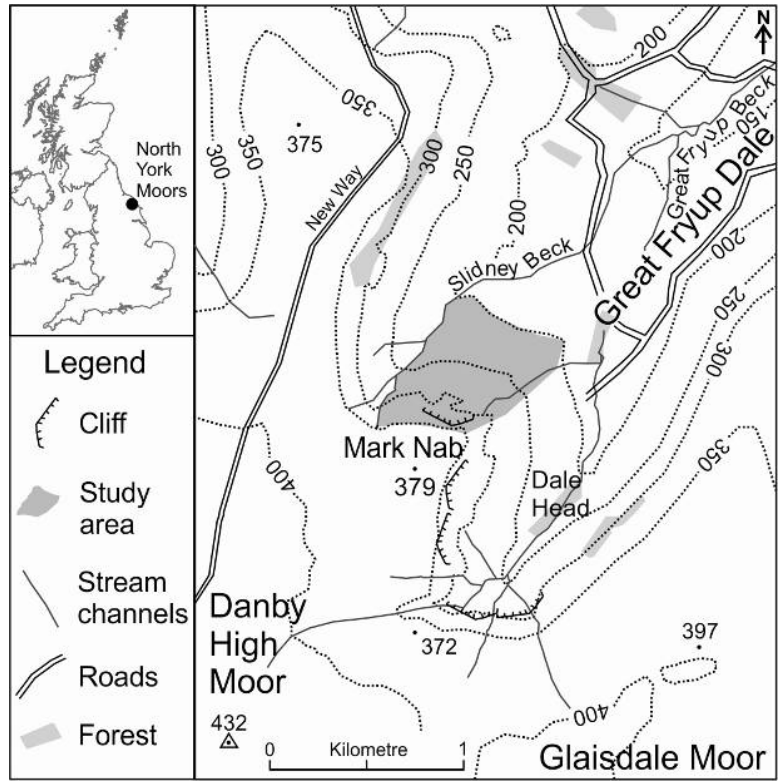

Fig. 2. Location map of the Mark Nab landslide study site at Great Fryup Dale, North York Moors.

88 Contours and spot heights are in metres above Ordnance Datum. Contains Ordnance Survey data C

Crown copyright and database right 2014.

\subsection{Bedrock geology}

92

The Great Fryup valley is cut into a bedrock succession of Lower to Middle Jurassic sedimentary rocks comprising units of mudstone, siltstone and sandstone, with subsidiary ironstone bands and limestone beds that together represent subsidence and eventual infilling of the Cleveland Basin (Kent et al., 1980; Holliday et al., 1992; Cox et al., 1999). The valley is positioned on the northern limb of the east-west trending Cleveland Anticline structure. The bedding in the valley is typically nearhorizontal but locally dips $1^{\circ}$ to $2^{\circ}$ to the north, dipping gently out of the slope below Nark Nab.

The succession comprises formations of the Lower Jurassic Lias Group, overlain by those of the Middle Jurassic Ravenscar Group. The typical lithologies of this succession are summarised in Table 1.

Table 1. Lithostratigraphic details and thickness of the bedrock sequence exposed in Great Fryup Dale (based on Kent et al., 1980; Howard, 1985; Powell et al, 1992; Young, 1994; Cox et al., 1999; Powell, 


\begin{tabular}{|c|c|c|c|}
\hline \multicolumn{3}{|c|}{ Lithostratigraphy and local thickness } & \multirow{2}{*}{$\begin{array}{l}\text { Lithology } \\
\text { Grey medium- to coarse-grained, pebbly, trough cross } \\
\text { bedded sandstone, with thin siltstone and mudstone } \\
\text { beds. Plant fragments and wood common. }\end{array}$} \\
\hline $\begin{array}{l}\text { Middle } \\
\text { Jurassic }\end{array}$ & $\begin{array}{l}\text { Ravenscar } \\
\text { Group }\end{array}$ & $\begin{array}{l}\text { Moor Grit } \\
\text { Member of the } \\
\text { Scalby Formation } \\
\text { c. } 15 \mathrm{~m}\end{array}$ & \\
\hline & & $\begin{array}{l}\text { Scarborough } \\
\text { Formation } \\
30 \mathrm{~m}\end{array}$ & $\begin{array}{l}\text { Variable lithology: fossiliferous argillaceous limestone, } \\
\text { calcareous mudstone, siltstone, and medium-grained } \\
\text { sandstone; calcareous concretions and ironstone. }\end{array}$ \\
\hline & & $\begin{array}{l}\text { Cloughton } \\
\text { Formation } \\
50-70 \mathrm{~m}\end{array}$ & $\begin{array}{l}\text { Laminated grey mudstone and siltstone with yellowish } \\
\text { grey, fine- to medium-grained, cross-stratified } \\
\text { sandstones and rare thin coals and seatearths. }\end{array}$ \\
\hline & & $\begin{array}{l}\text { Eller Beck } \\
\text { Formation } \\
4.5-6 \mathrm{~m}\end{array}$ & $\begin{array}{l}\text { Upward-coarsening succession of mudstone (with } \\
\text { ironstone concretions), siltstone and fine- to medium- } \\
\text { grained sandstone. Sandstone commonly ripple } \\
\text { laminated, yellow weathering, bioturbated. }\end{array}$ \\
\hline & & $\begin{array}{l}\text { Saltwick } \\
\text { Formation } \\
\text { c. } 37 \mathrm{~m}\end{array}$ & $\begin{array}{l}\text { Grey mudstone, yellow-grey siltstone and fine- to } \\
\text { coarse-grained sandstone. Cross stratified, non- } \\
\text { bioturbated. Sandstone beds and channel fills. Thin } \\
\text { coals, seatearth mudstone and nodular ironstone, plant } \\
\text { fragments, rootlets common in some beds. }\end{array}$ \\
\hline & & $\begin{array}{l}\text { Dogger Formation } \\
7-8 \mathrm{~m}\end{array}$ & $\begin{array}{l}2 \text { to } 3 \mathrm{~m} \text { thick beds of deep-red poorly sorted coarse- } \\
\text { grained sandstone, with chamositic (green) ooliths and } \\
\text { scattered rounded granules and pebbles. }\end{array}$ \\
\hline \multirow[t]{3}{*}{$\begin{array}{l}\text { Lower } \\
\text { Jurassic }\end{array}$} & \multirow[t]{3}{*}{$\begin{array}{l}\text { Lias } \\
\text { Group }\end{array}$} & $\begin{array}{l}\text { Blea Wyke } \\
\text { Sandstone } \\
\text { Formation } \\
\text { c. } 5 \mathrm{~m}\end{array}$ & $\begin{array}{l}\text { Micaceous, fine-grained sandstones: grey-weathering } \\
\text { and argillaceous in lower part, yellow-weathering and } \\
\text { silty in the upper part. }\end{array}$ \\
\hline & & $\begin{array}{l}\text { Whitby Mudstone } \\
\text { Formation } \\
\text { Locally c. } 90 \mathrm{~m}\end{array}$ & $\begin{array}{l}\text { Medium and dark grey fossiliferous mudstone and } \\
\text { siltstone, laminated and bituminous in part, with this } \\
\text { siltstone or silty mudstone beds. Sporadic thin sideritic } \\
\text { and calcareous beds, limestone and phosphatic nodules } \\
\text { and concretions. Pyritic. }\end{array}$ \\
\hline & & $\begin{array}{l}\text { Cleveland } \\
\text { Ironstone }\end{array}$ & $\begin{array}{l}\text { Grey silt-laminated mudstone with up to six } 0.1 \text { to } 0.3 \mathrm{~m} \\
\text { thick interbeds of hard, fossiliferous, ooidal ironstone }\end{array}$ \\
\hline
\end{tabular}




\begin{tabular}{|l|l|l|}
\hline & $\begin{array}{l}\text { Formation } \\
\text { Up to c. } 25 \mathrm{~m}\end{array}$ & (siderite and berthierine). \\
\cline { 2 - 3 } & $\begin{array}{l}\text { Staithes } \\
\text { Sandstone } \\
\text { Formation }\end{array}$ & $\begin{array}{l}\text { Silty sandstone with 2 to 4 m thick packages of } \\
\text { laminated fine-grained sandstone in the middle and } \\
\text { upper parts: typically bioturbated and/or showing wide } \\
\text { variety of bedding structures. }\end{array}$ \\
\cline { 2 - 4 } & $\begin{array}{l}\text { Redcar Mudstone } \\
\text { Formation }\end{array}$ & $\begin{array}{l}\text { Grey, fossiliferous, fissile mudstones and siltstones with } \\
\text { subordinate thin beds of shelly limestone below, fine- } \\
\text { grained carbonate-cemented sandstone above: } \\
\text { argillaceous limestone concretions occur thoughout. }\end{array}$ \\
\hline
\end{tabular}

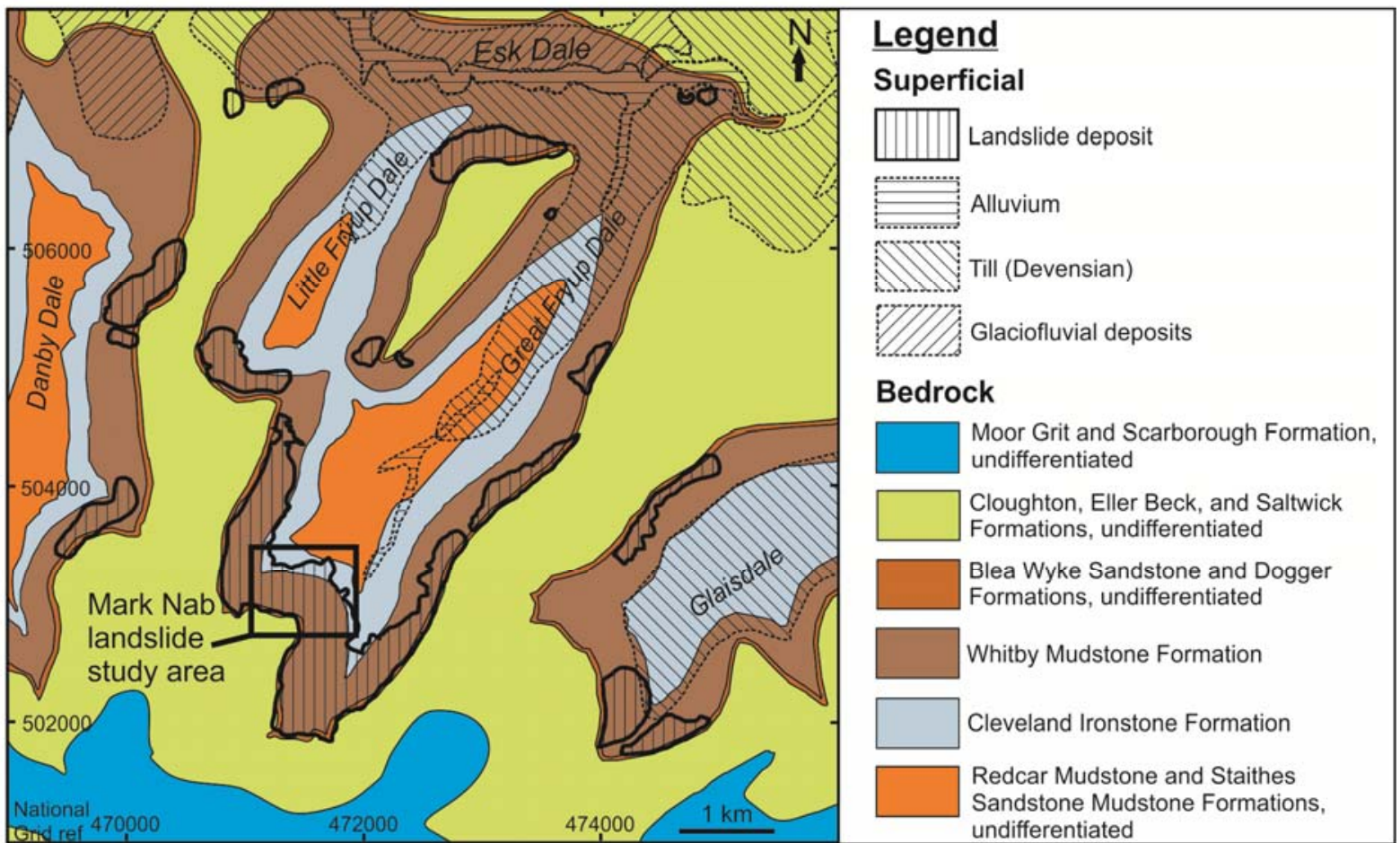

Fig. 3. Geological map of Great Fryup Dale, adapted from Holliday et al. (1992), Sheet 43 Solid and

Drift Edition, with unpublished BGS landslide deposit mapping data. Contains British Geological

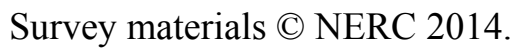

111 The overview geological map in Fig. 3 shows that landslide deposits are extensive in Great Fryup

112 Dale and are largely coincident with the Whitby Mudstone Formation (WHB) and Dogger and Blea 
Wyke Formations. The Whitby Mudstone Formation is predominantly argillaceous and locally c. 90 $\mathrm{m}$ thick, comprising grey to dark grey, finely laminated, fissile, pyritic mudstone and silty mudstone with sporadic thin sideritic and calcareous beds and concretions (Powell, 2010; Table 1). The formation comprises five lithologically distinct Members (Cox et al., 1999) each displaying slightly different geotechnical properties. This subtle variation in physical properties strongly influences landslide mechanism, scale, style and preservation potential across the region and the details of individual member beds is worthy of description and some discussion here. Of particular importance to slope stability is the presence of 'slide-prone horizons' within argillaceous units, as defined by Bromhead and Ibsen (2004), which give rise to bedding controlled failures. The finely laminated (fissile) nature and pyrite content of some beds creates strength anisotropy. The basal unit of the Whitby Mudstone Formation, the Grey Shale Member, consists of c.14 m of pale grey, locally pyritic, silty mudstone with calcareous siderite concretions (Powell, 2010). A change to anoxic conditions are reordered in the overlying Mulgrave Shale Member, which is c. $31 \mathrm{~m}$ thick and includes $9-10 \mathrm{~m}$ of fissile, finely laminated, bituminous, dark grey mudstone (previously 'Jet Rock') with horizons of calcareous concretions and a thin pyritic limestone at the top (previously 'Top Jet Dogger'), passing up into c. $23 \mathrm{~m}$ of fissile, bituminous mudstone with abundant ammonites (formerly 'Bituminous Shales'). The Alum Shale Member above is c. $37 \mathrm{~m}$, comprising a lower soft grey silty (micaceous) mudstone that includes c. $6 \mathrm{~m}$ of non-bituminous shale capped by a band of siderite nodules, overlain by c. $15 \mathrm{~m}$ of pyritic shale (the main 'Alum Shales'), then 13-20 m of harder shale (formerly 'Cement Shales') that include beds of calcareous nodules (Kent et al., 1980; Powell, 2010). The Middle Jurassic Dogger Formation rests unconformably on the Alum Shales in this part of the Cleveland Basin and the overlying Peak Shale and Fox Cliff Members exposed along the Yorkshire coast near Whitby are absent (Powell, 2010).

Kent et al. (1980) interpreted the overall structural grain of the regions distinct sub-parallel valleys to

137 be the result of basin inversion, uplift, erosion and unloading. This structural history produced a pervasive radial joint pattern which had led to the development of the distinctive radial drainage pattern. In the north of the Moors the predominant N-S structural grain and topography led to the 
formation of a series of near-parallel north-south orientated valleys, and Great Fryup Dale serves as a

141 fine example of one of these consequent drainage features. Joints are pervasive and laterally and

142 vertically persistent in the sandstone beds that cap the mudstones, and are generally orientated near-

143 parallel to the valley slopes. The presence of these joints, together with occasional faults, reduces the

144 mass strength of the cap rock and Dogger Formation beds in a preferential orientation, and also

145 increases the permeability and storage capacity of these units (creating aquifers). These structural

146 factors, along with the presence of weak horizons, strongly control landslide susceptibility and

147 mechanisms of failure.

\subsection{Quaternary history}

Great Fryup Dale was glaciated through the Devensian and became de-glaciated in late-Devensian times (Jones, 1977; Jones, 1999). During the Last Glacial Maximum (LGM) of Marine Isotope Stage 2 (around $18000 \mathrm{yrs}$ BP), the high ground on the North York Moors remained largely ice free but experienced very severe periglacial conditions (Innes, 1999; Innes et al., 2009; Chiverrall and Thomas, 2010). At this time the valley was probably fully glaciated by a tongue of ice from a glacier in the Esk Valley (Kendall, 1902; Kent et al., 1980; Chiverrell and Thomas, 2010; Murton and Murton, 2011). De-glaciation commenced c. $13000 \mathrm{yrs} \mathrm{BP,} \mathrm{in} \mathrm{the} \mathrm{Late} \mathrm{Glacial} \mathrm{Interstadial} \mathrm{but} \mathrm{was}$ interrupted by a brief final cold stage between about 10800 and 10400 yrs BP, during the Loch Lomond Stadial (Innes, 1999). Glaciation left patchy deposits of till in the valley floor (Fig. 3) and prolonged periglacial conditions left spreads of periglacial Head deposits across slopes. Holocene rivers cut down through till, deposited alluvium across the valley floor, and cut terraces into the bedrock. Landslide deposits formed in oversteepened valley heads and along valley sides, sometimes blocking stream channels which temporarily diverted river flow. On the hill tops peat deposits cover much of the plateau, which along with some valley slopes to the south (e.g. Rosedale) are peppered with shallow coal and ironstone workings and small mine spoil heaps. 


\section{Slope geomorphology at Mark Nab}

167 The landslide at Mark Nab is c. $700 \mathrm{~m}$ long and c. $600 \mathrm{~m}$ wide; it covers approximately $0.36 \mathrm{~km}^{2}$

168 (Figs. 3 and 4). The crown of the landslide is at an elevation of c. $340 \mathrm{~m}$ aOD, and the toe is at c.

$169190 \mathrm{~m}$ aOD. The flanks abut against adjacent landslide deposits to the east and west.

\subsection{LiDAR interpretation}

172 Airborne LiDAR data were acquired by the Environment Agency Geomatics Group at a resolution of

$1730.25 \mathrm{~m}$ (flown March 2012). The derived shaded digital terrain model (Fig. 4) was interpreted and

174 main landslide features initially mapped out using a GIS and adopting the descriptive terms from

175 Cruden and Varnes (1996). Based on this mapping and supplementary detailed field-based mapping,

176 three distinct morphological zones (I-III) were identified within the one landslide system:

177 Zone I - rear scarp with rockfall

178 Zone II - main body with rotated landslide blocks, block disruption, minor scarps and grabens

179 Zone III - frontal mudflow complex with concealed block disruption or weathered bedrock

180 The following section describes the geomorphology of the slope as interpreted from the LiDAR data 181 (Fig. 4).

182 The average slope angle on the landslide varies widely; a concave near vertical cliff dominates Zone I, whereas slopes of up to $42^{\circ}$ are locally present in Zone II. The lower slopes in Zone III are generally smooth and gently undulating with an overall convex form downslope. 


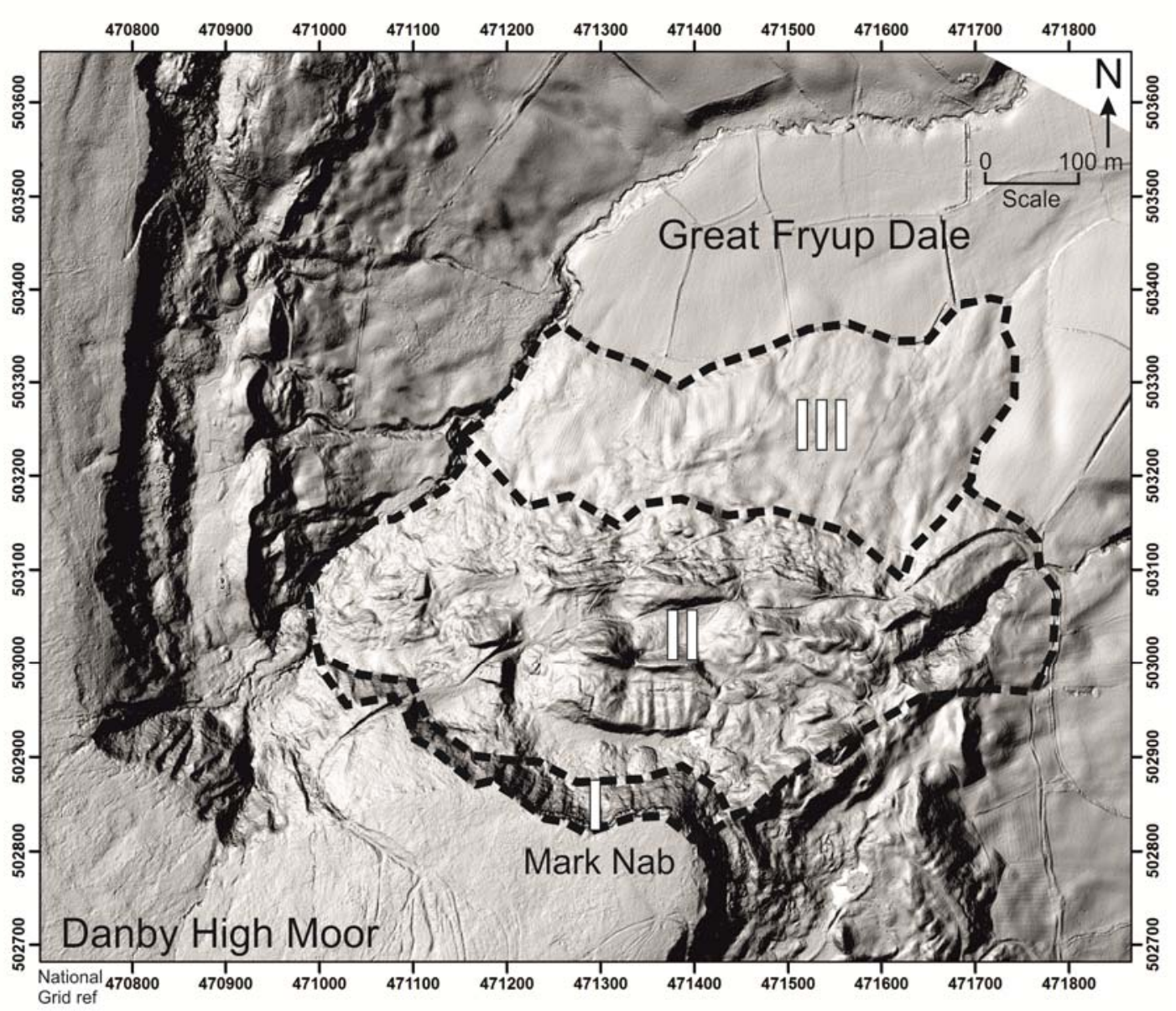

Fig. 4. Use of high-resolution LiDAR. A derived Digital Terrain Model of Great Fryup Dale $(0.25 \mathrm{~m}$ $\mathrm{x}, \mathrm{y}$, resolution, $0.015 \mathrm{~m}$ vertical resolution, flown by Environment Agency 10 March 2012).

Coordinate system is British National Grid. Three main morphological zones (I-III) are defined based on surface morphology.

\subsubsection{Details of Zone I}

Zone I contains the rear scarp of the landslide, which is c. $370 \mathrm{~m}$ long, up to $40 \mathrm{~m}$ high. This feature

forms a sharp crescent shaped cliff separating the sheltered valley from the exposed moorland plateau.

The upper portion of scarp is a near vertical $6 \mathrm{~m}$ high cliff exposing thickly bedded gritty sandstone

blocks of the Cloughton Formation (Sycarham Member) and the finer more thinly bedded Eller Beck

Formation below. The rock mass is locally regularly jointed and blocky, with three orthogonal joint 
sets present; oriented ESE, SE and NE. These joints intersect the near-horizontal bedding which daylight in the cliff face. This kinematic geometry favours 'toppling' and 'sliding' modes of failure, and failures typically releasing fairly large $\left(1\right.$ to $\left.3 \mathrm{~m}^{3}\right)$ blocks of sandstone, which have accumulated in a talus cone at the foot of the main scarp, partially filling the surface depression formed by the rear graben.

The lower half of the escarpment cliff (main scarp) exposes mudstones and sandstones of the Saltwick Formation. Continued erosion of the cliff has deposited a thin veneer of 'gravelly clay' on the slope which periodically fail in translational debris-rich mud slides also feed fluidised sediment, sometimes via chutes, into the depression below (graben). Several freshwater springs emerge from Sycarham Member along the base of the main sandstone cap, and also from several sandstone channels present within the predominantly silty Saltwick Formation. Erosion by these springs forms small gullies in the backscarp, and fossil gullies are preserved on the eastern most rear landslide block.

The western side of the escarpment slope has undergone differential erosion leading to bevelling of the bedrock surface (Cloughton Formation) which has produced a more rounded profile in the east. Above Zone I, at the western end of the main scarp, is a north-west-facing slope facet, with a distinctively smooth, regular, and convex profile which becomes progressively steeper downslope $\left(19-26^{\circ}\right)$. This slope is mantled with at least $2-3 \mathrm{~m}$ of soliflucted head deposits composed of stiff grey slightly gravelly, silty, sandy clays with rare rounded pebbles. These pebbles may have been reworked from a pre-Devensian till. This slope is also scattered with large rounded boulders of coarse-sandstone and are notably more deeply weathered than the rockfall blocks from the back scarp. It is most likely that this slope facet is a periglacial 'boulder field' with boulders sourced from the thick sandstone bed that crops out at the crest of the slope (see Fig. 5). Another such 'boulder field' is present on an eastfacing slope facet located c. $200 \mathrm{~m}$ to the west, on the opposite side of the valley.

\subsubsection{Details of Zone II}


222 The upper part of Zone II contains a $30 \mathrm{~m}$ wide, $200 \mathrm{~m}$ long, flat waterlogged depression. This is

223 interpreted as a rear graben that separates the rear scarp from the main body of the landslide. The

224 graben contains $0.5 \mathrm{~m}$ of peat over at least $2 \mathrm{~m}$ of wet soft silt. A low man-made earth dam (built $\mathrm{c}$.

225 2010) impounds excess surface and spring water in the graben formed depression to supply nearby

226 farms.

227 The middle part of Zone II contains a c. $200 \mathrm{~m}$ long area of highly irregular topography characterised

228 by massive blocks, each c. $100 \mathrm{~m}$ wide and c. $60 \mathrm{~m}$ long, with secondary slope parallel scarps up to

$22920 \mathrm{~m}$ high. The highest blocks are capped by a band of resistant ferruginous limestone of the Blea

230 Wyke Member and are composed mostly of Whitby Mudstone Formation mudstone. These beds dip

231 at c. $20^{\circ}$ to the south in the rearmost blocks, but the dip increases to up to c. $58^{\circ}$ on the frontal blocks.

232 The edges of the main landslide blocks are markedly linear and strike NNE, as can be clearly seen

233 from the LiDAR DTM (Fig. 4). This orientation matches the principal joint set orientation (measured

234 in sandstone exposed in the main cliff above), suggesting an inherent structural control on landslide

235 morphology. Small ponds occur in depressions between the main landslide blocks and are filled by

236 several metres of laminated silt with occasional cobbles (proved by Russian Corer and hand

237 auguring). The topography of the eastern side of Zone II is generally more subdued than the western

238 side following more intense reworking and infilling of topographic depressions by mudflows

239 generated by high amounts of water issuing from the springs and small springs that drain the rear

240 pond.

241 The eastern flank of the main landslide is represented at surface by a c. $150 \mathrm{~m}$ long, $15-20 \mathrm{~m}$ high

242 scarp feature which forms a linear trough. It is currently occupied by a stream fed by the rear pond

243 and is bounded to the east by a ridge composed of slipped fissile mudstone capped by a red sandstone.

244 The western margin of Zone II represents the western flank; this area of rough ground is characterised

245 by a complex association of morphological features created by a series of superficial shallow multiple

246 landslides formed in the pre-slipped mudstone, similar in style to the lowest part of Zone II. Slope

247 instability in this part of Zone II is primarily driven by toe erosion by Slidney Beck. The course of this 
stream has clearly been obstructed, and likely dammed, by landslide deposits on multiple occasions, and diversion of the stream has carved new channels and fluvial terraces, and proceeded to undercut other suspended landslide deposits.

Below the $270 \mathrm{~m}$ contour line morphology in Zone II is typically more subdued with 5-10 $\mathrm{m}$ high minor scarps and transverse tension cracks that run parallel with the slope. The lowest slopes in Zone II consists solely of mudstone beds (with sandstone absent) which are rotated by up $45^{\circ}$ in boreholes 2 and 3. Contorted tightly folded beds of mudstone are exposed in a track cutting and stream section at the toe (locations 3-5 in Fig. 5). It is likely that this lower area contains the main slip surface breakout, and although the shear surfaces are masked by superficial slumped mudstone, their surface expression can be traced along a slight rise in ground level.

\subsubsection{Zone III}

Zone III is typically smoother than Zones I and II, with irregular slopes of c. 9-12 ${ }^{\circ}$. This zone contains the foot and toe of the landslide. This zone is c. 200-300 m long, c. $600 \mathrm{~m}$ wide and contains degraded mudflow lobes, peat hollows and some spring lines. The toe area has been artificially drained to improve the quality of the pasture land. The western side has degraded ridge and furrow plough lines which are disturbed above the $245 \mathrm{~m}$ contour line where grass pasture gives way to bracken and the ground is crossed by degraded transverse cracks.

Below Zone III the ground is very smooth and slopes gently to the north. This area is interpreted to preserve a glacially eroded surface which has later been modified by streams emanating from the toe of the landslide, and diverted around the toes of other landslide masses that have previously dammed Slidney Beck. These stream diversion events have likely caused erosion of the toe, evidenced by a low cliff feature along the western end of the toe. 
The morphological features interpreted from the LiDAR were combined with detailed geological field

274 mapping to produce a 1:2 500 scale 'geomorphologic plan' (Fig. 5; as per Anon, 1972; Griffiths,

275 2002; Fell et al., 2008). The plan depicts the key morphological features and geology, with structural

276 data, field localities (numbered locality 1-13), borehole and dynamic penetrations test locations,

277 geophysical survey lines, and lines of cross-section. The Cloughton and Saltwick Formations are

278 exposed in the main back scarp and erosion of these materials contributes to rockfall, mudslides and accumulation of tallus (Loc. 13). On the main body (Zone II) several Whitby Mudstone cored blocks are capped by the more resistant sandstone and limestone beds of the Dogger and Blea Wyke formations. Their lithologically distinctive beds provide key stratigraphic markers across the slipped ground, and their southerly dips and drop in elevation, provide evidence for back rotation of the landslide mass. The extents of these marker beds was mapped out in detail, with structural measurements taken to help model the subsurface structure of the landslide blocks. Periglacial head deposits above and west of the main backscarp are truncated by the rear scarp exposing the nonmarine siltstone and mudstones of the Saltwick Formation. This relationship has important implications for the landslide movement history, as discussed later. On the far western flank, Slidney Beck has been diverted around the toe of a secondary landslide deposit shows a cross section through this part of the slope). The scarp of this toe failure truncates the main scarp feature and this provides evidence for erosion-driven reactivation after the main failure, although the relative age of this subsequent failure has not yet been investigated. The steam is currently eroding the river bank at the foot of Zone II, and thereby continues to destabilise the western side of the landslide system. In the upper part of Zone III the sharpness of minor scarps, which define the boundaries of the secondary rotations through 'block disruption' (9 and 10), and tension cracks (11) have become much degraded. The disrupted Whitby Mudstone Formation mudstone slakes fairly readily and has degraded to mud which feeds into flows that supply material to the lower mudflow complex (6) producing a smooth slope profile (7 and 8) across the crop of the Cleveland Ironstone Formation bedrock surface. Contorted and tightly folded beds of mudstone are well exposed in a sunken track (4 and 5) in the eastern toe area. These structures are interpreted as a product of compression related to landsliding, 


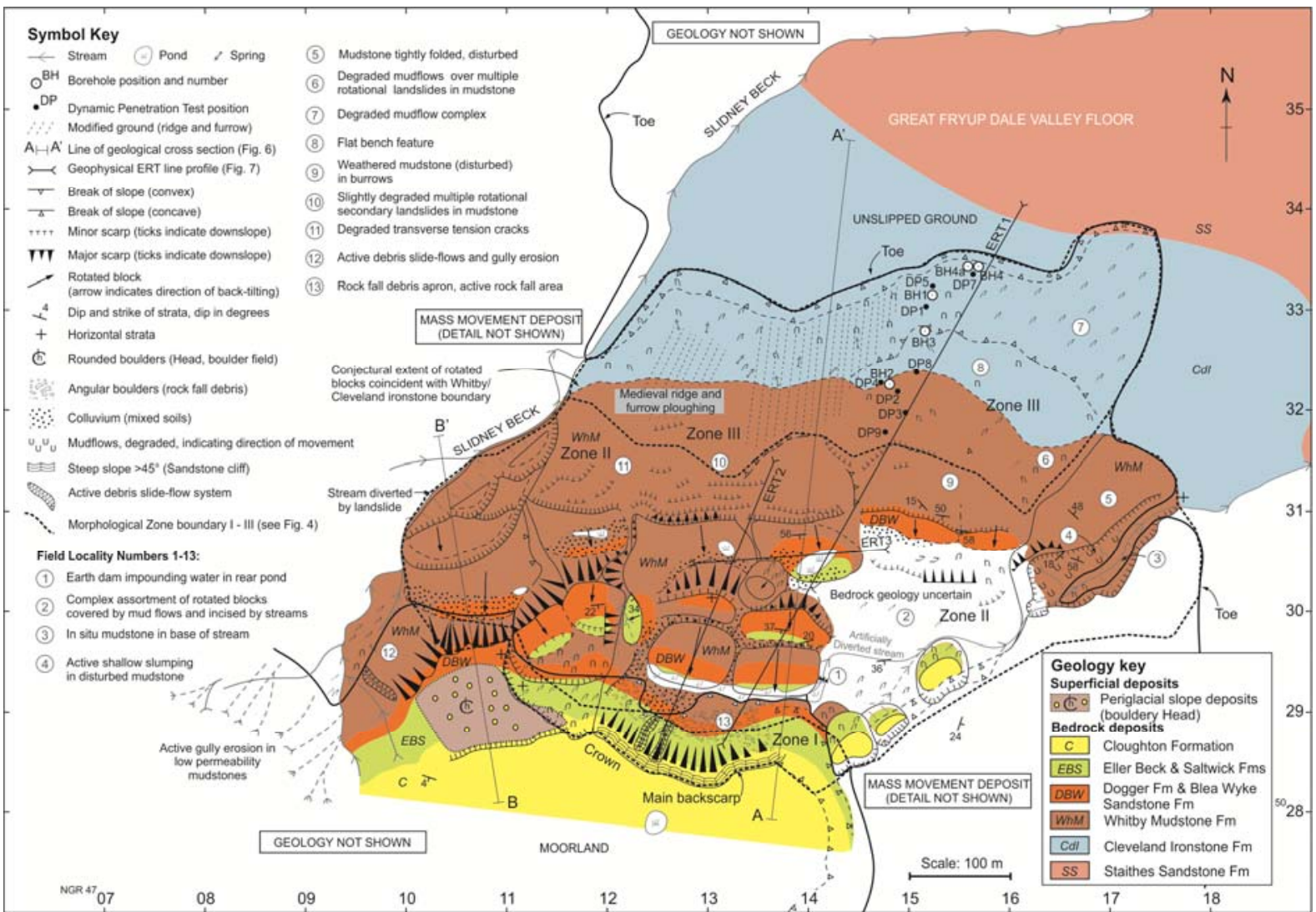

304 Fig. 5. Geomorphologic plan of the Mark Nab landslide showing key localities, positions of boreholes

305 (BH1, 2, 3, 4, 4A), dynamic penetration tests, ERT lines (ERT1, 2, 3), geological cross section lines A 306 and B, and relation of surface morphological features to the landslide morphological Zones I-III defined in Fig. 4. 


\section{Subsurface investigations}

310

311

312

313

314

315

316

317

318

319

320

321

322

323

324

\subsection{Drilling and testing}

Five boreholes $(1,2,3,4,4 \mathrm{~A})$ were drilled in the foot of the landslide to assess the stratigraphy and to provide ground-truth for the geophysics. The boreholes (BH) were logged to British Standards for Site Investigation (BS5930,1999; BS EN ISO 14688-1 and weathering described according to Anon, 1995). Full logs are presented in Appendix 1and BH locations shown in Fig. 5. The core was sampled in a fresh state for classification tests, including moisture content, bulk density, resistivity and shear strength (unconsolidated undrained for 'peak' values, and consolidated drained for 'residual' values). The BH 4A was a re-drill of BH4 drilled to collect additional samples.. Dynamic Penetrometer (DP) tests were also undertaken to provide correlation of hard and soft zones between boreholes. The DP's were progressed to refusal $(N \geq 60)$, terminating within unslipped mudstone or harder ironstone or siderite bands. A standpipe piezometer installed in BH2, located in Zone III, to monitor shallow groundwater levels, and was monitored between March to November 2012 using a Solnist level logger and barometric logger at $15 \mathrm{~min}$. intervals. Within the monitoring period the water level fluctuated between 2.8 and $3.5 \mathrm{~m}$ below ground surface and was sensitive to antecedent rainfall conditions. It is unlikely that this water level represents the water table across the entire landslide, as groundwater conditions are likely to be complex, and possibly compartmentalised in Zone II due to minor aquifers occurring within individual landslide blocks.

The boreholes in Zone III (BH's 1, 3, 4, and 4A) proved weak mudstone bedrock (Whitby Mudstone Formation) overlain by c. $10 \mathrm{~m}$ of soft to firm mottled or laminated clay sediments (mudflows).

Borehole 2, located further up slope within Zone II, proved $6 \mathrm{~m}$ of rotated mudstone beds interpreted as slipped Whitby Mudstone Formation. Boreholes 4 and 4A, in the toe area, proved several metres of deeply weathered mudstone overlain by stiff gravelly clay (head or till) deposits, and capped by soft clay containing an organic-rich peaty soil horizon between 2.64 and $2.90 \mathrm{~m}$ b.g.l. These organic rich horizons, which were dated (see later), are interpreted as a palaeosol that formed in a small depression subsequently buried and preserved by a mudflow event. 
The Electrical Resistivity Tomography (ERT) technique (Jongmans and Garambois, 2007) was used to compare subsurface characteristics with surface features and ground-truth from borehole data.

Geophysical surveys were acquired along three lines: ERT Lines 1,2 and 3, and these were orientated perpendicular to major structural trends and geological boundaries, including the main landslide blocks. Line ERT1 was acquired using two arrays (ERT 1A and 1B) in order to sample the entire length of the landslide deposit, and including the lower non-slipped ground beyond the toe. The survey design provided for a depth of investigation up to c. $50 \mathrm{~m}$ in order to image the shallow and deep structure of the landslide beyond the estimated depth of the deepest slip surface, based on initial cross sections and the geomorphological evidence.

Approaches to ERT field surveying are described widely in the literature (e.g. Chambers et al., 2011; Lapenna et al., 2005), so only a brief explanation is provided here. The ERT field survey was undertaken during May 2011. ERT data were collected using an AGI SuperSting R8 IP system attached to stainless steel electrodes via multicore cables. Ground conditions were generally extremely dry. To reduce contact resistances and improve data quality, each electrode was watered using a saline solution. Electrode positions were identified using survey tapes extended across the ground surface; a real-time-kinematic (RTK) GPS measurement, with centimetric accuracy, was then made for each electrode position, to establish the grid position and elevation of each electrode.

The locations of the four ERT Lines 1A, 1B, 2 and 3 are shown in Fig. 5 as ERT1, ERT2, and ERT3 with lengths of 292.4, 307.6, 289.5 and 184.9 m respectively. (note ERT 1A and 1B are end on and are depicted as ERT 1 in Figure 5). A dipole-dipole configuration was employed for each of the lines. The longer lines, Lines 1A, 1B and 2, were surveyed using (along-ground) dipole lengths $(a)$ of 5, 10, 15,20 , and $25 \mathrm{~m}$ and dipole separations $(n a)$ of $1 a$ to $8 a$. For Line 3 , which was a shorter and higher resolution imaging line, dipole lengths $(a)$ of $3,6,9,12,15$, and $18 \mathrm{~m}$, and dipole separations $(n a)$ of $1 a$ to $8 a$ were used. 
361 A summary of the contact resistances and reciprocal error characteristics of the ERT Lines 1A, 1B, 2,

362 and 3 are shown in Table 2. Even with watering, the measured contact resistances were relatively

363 high, with mean resistances of approximately $3,000 \Omega$, reflecting the very dry conditions at the time.

364 The reciprocal errors do however indicate that reasonable data quality was achieved for most

365 measurements (i.e. $>80 \%$ of the measured reciprocal pairs had a reciprocal error of $<1 \%$ ). Data points

366 with a reciprocal error of $>1 \%$ were removed from the data sets, and the reciprocal errors were used to

367 weight the data during the inversion. The misfit errors for ERT Lines 1A, 1B, 2 and 3 were 2.4\%,

$3681.1 \%, 3.4 \%$ and $2 \%$ respectively indicating good convergence between the model and measured data.

370 Table 2. Contact resistance and reciprocal error summary information for ERT Lines 1A, 1B, 2 and 3.

\begin{tabular}{lcccccc}
\hline & \multirow{2}{*}{$\begin{array}{c}\text { Number of } \\
\text { measurements* }\end{array}$} & \multicolumn{2}{c}{$\begin{array}{c}\text { Contact resistance } \\
\text { (Ohms) }\end{array}$} & & \multicolumn{2}{c}{$\begin{array}{c}\text { Fraction (\%) of data set below } \\
\text { reciprocal error level }\end{array}$} \\
\cline { 3 - 4 } & 1780 & 3159.0 & 4145.9 & & 80.6 & $5 \%$ \\
\hline Line 1A & 1788 & 2757.0 & 1735.6 & & 80.0 & 95.0 \\
Line 1B & 1780 & 3065.0 & 2656.2 & & 83.3 & 96.6 \\
Line 2 & 1980 & 3175.0 & 1872.2 & & 87.6 & 99.1 \\
\hline
\end{tabular}

*Each comprising a reciprocal pair (i.e. a fo rward and reciprocal measurement)

371

** standard deviation (SD)

372 It should be noted that ERT models are smoothed images for which resolution decreases with

373 increasing depth of investigation because the model in these regions is less well constrained by the

374 data. The interpretation of 2D ERT imaging data is further complicated by off-line 3D resistivity and

375 topographic variations that violate the $2.5 \mathrm{D}$ assumption. Therefore, the ERT images can provide only

376 an approximate guide to the true resistivity and geometry of subsurface features (Olayinka and

377 Yaramanci, 2000; Chambers et al., 2002); and hence, calibration and interpretation using other

378 sources of ground-truth information are highly desirable. This was possible in Zones I and III, where

379 exposure mapping or borehole data were available, but not in Zone II. 
The ERT survey Lines 1A, 1B, 2 and 3 (Fig. 6) provide additional information on deep subsurface structure and composition of the landslide mass. The geophysical models for the corresponding ERT Lines 1A, 1B, 2 and 3 are presented in Fig. 6 with borehole and penetrometer test data overlaid to provide information on material characteristics and depths, where available. The low resistivity areas generally correspond with clay-rich materials, such as mudstone lithologies and wet clay soils, and these contrast against more electrically more resistive areas which indicate other materials such as siltstone, sandstone, limestone or free draining dry coarse or very coarse soils. Geological boundaries, depicted in black, are projected into the subsurface and geological units labelled. Oblique formation labels indicate rotated bedding and horizontal labels indicate horizontal bedding. The relationship and distribution of high and low resistivity zones at depth within the main body of the landslide (ERT Lines 1A, 2 and 3) provide evidence of the deep structure where there is no intrusive investigation. Truncation of rectangular high resistivity zones against low resistivity zones in Zone II is interpreted as evidence for rotation and juxtaposition of more resistive beds (e.g. partially or un-saturated sandstone and limestone beds) against low resistivity mudstones. The dashed white lines depict 'inferred' positions of the main shear surfaces with arrows indicating direction of slip. In Zone II the geophysical data suggest a c.30 m deep 'upper' slip surface, with an entirely separate 'lower' slip surface. In Zone III the lateral thickness variation in mudflow deposits within the toe can be inferred, with borehole control, from the geophysical model (ERT Line 1, Fig. 6) where the boundary is marked by a sharp transition between lower resistivity zones representing mudstone and higher resistivity, zones representing sandy clay and silt rich materials. 

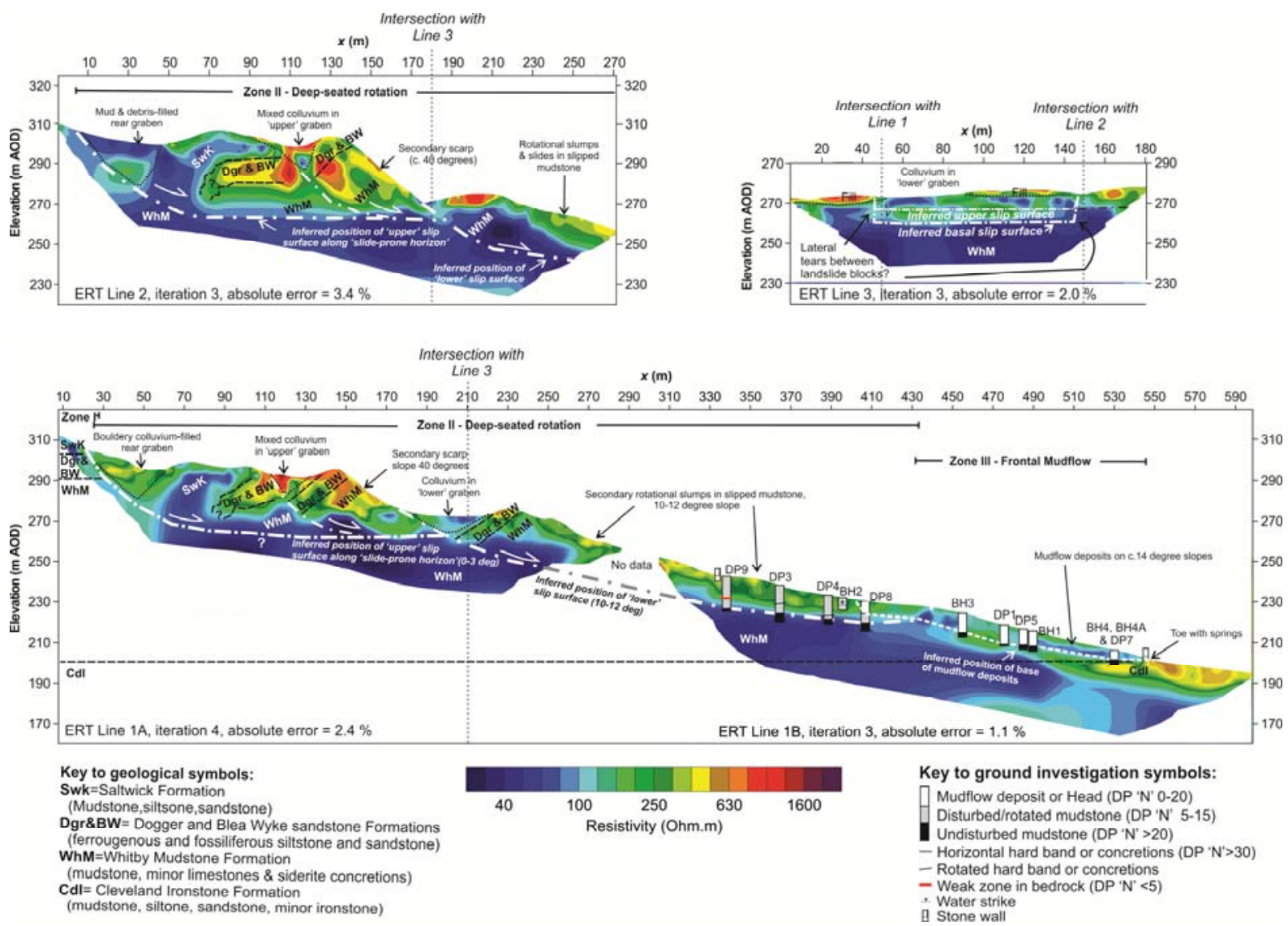

404 Fig. 6. ERT sections from the Mark Nab landslide with borehole data and preferred interpretation of

405 profile of main slide surface.

\section{5. Slope architecture}

408 An interpretation of the 2D architecture of the slope has been developed by combining the LiDAR

409 digital terrain model (Fig. 4), geology map and geomorphological interpretation (Fig. 5) and the

410 findings of the drilling and geophysics (Fig. 6), following the 'total geological model' approach

411 described by Fookes (1997). The model of the internal architecture and its relation to the bedrock

412 succession is summarised in two cross-sections, Section A and B, in Fig. 7. The location of Section lines $\mathrm{A}$ and $\mathrm{B}$ are shown in Fig. 5. 

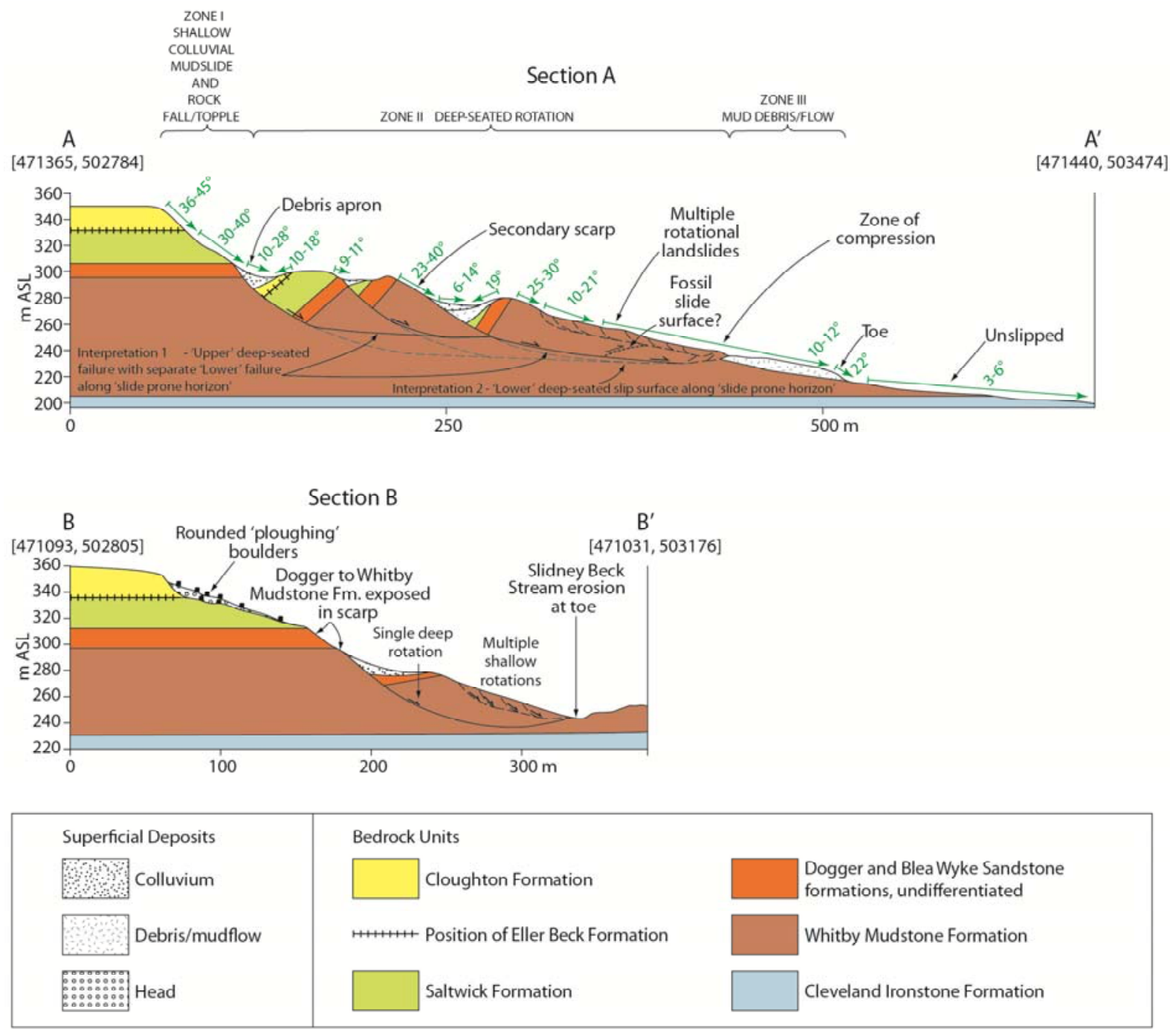

415 Fig. 7. Section A: Idealised geological cross section through centre of the Mark Nab landslide

416 showing two possible slip surface geometry interpretations: Interpretation 1 entertains two entirely

417 separated slide surfaces, the 'upper' surface is bedding-controlled and horizontal, the 'lower' is a sub-

418 horizontal non-bedding-controlled surface; while Interpretation 2 considers a multiple rotation with

419 three main blocks and a common basal bedding-controlled slide surface. Zones I-II relate to

420 geomorphological zones described in Fig. 4. Section B: Idealised cross section though the western

421 flank with single compound slide with superficial rotations. Note the location of the cross section

422 lines do not match the location of the geophysical survey lines (see Fig. 5).

424 Section A (A-A', Fig. 7) shows an idealised geological cross section through the centre line of the landslide and subsurface relationships between surface morphological features, such as back-tilted 
sandstone-capped mudstone blocks and key geological marker beds such as the Dogger Member. At

427 the rear of the escarpment (Zone I), the thick horizontally bedded cap rock of well-jointed sedimentary rocks, composed of Dogger Member, Saltwick Formation, Eller Beck Member and predominantly Cloughton Formation, provide a static load on the thick Whitby Mudstone Formation beds. These non-argillaceous units effectively behave as a layered aquifer which along with surface infiltration supply water into the slope. Dilation of existing bedrock joints due to vertical and lateral stress-relief (unloading) has contributed to enhanced bulk porosity and permeability of the cap rock and is an important factor in the hydrogeology.

The presence of three large internal blocks within Zone II (deep-seated rotational) suggests that at least two internal slide surfaces are present, and these likely connect with the main slide surface at depth (Fig. 6, Section A). There are several possible interpretations of the slip surface geometry, and the author's two preferred interpretations are labelled in Fig. 6 as Interpretation 1 and 2. The first interpretation involves an 'upper' slip surface, with a c. $30 \mathrm{~m}$ deep sub-horizontal planar surface which follows a 'slide prone horizon', as defined by Bromhead and Ibsen (2004), within the Whitby Mudstone (upper beds of the Mulgrave Shale Member), and a completely separate 'lower' slip surface evidenced by the geophysics, which is c. $20 \mathrm{~m}$ deep and gently inclined at c. $10-12^{\circ}$. The form of the 'lower' slip surface is sub-horizontal, planar or stepped, and cuts through the bedding of theWhitby Mudstone (Mulgrave Shale Member). Both slip surfaces are most likely non-circular.

However, an alternative interpretation (Interpretation 2) is also worth consideration. This involves a single deeper-seated non-circular slip surface that cuts through to the base of the Whitby Mudstone Formation. The maximum depth of rupture for this interpretation is c. $50 \mathrm{~m}$, somewhat deeper that interpretation 1, with the slide plane exploiting the full depth of the mudstones of the Mulgrave Shale Member, probably along a landslide prone horizon at or near the base of the formation (bedding plane failure). The simplest geometrical solution supported by geophysical and borehole evidence is Interpretation 1 . However, there is some uncertainty about the reliability of the geophysical data at depths beyond $30 \mathrm{~m}$, and so the interpretation of the structural interpretation in Zone II is still largely based on expert judgement. 
453 Section B of Fig. 7, which corresponds to B-B' in Fig. 5, is a representation of the western side of the

454 Mark Nab landslide complex. The section depicts the form of the main slide surface at the far western

455 flank as topped by shallow multiple rotations. Erosion of the toe of the landslide mass by Slidney

456 Beck continues to destabilise this part of the Mark Nab landslide system, and this is a process that is

457 actively occurring to the south at the heads of the Great Fryup Valley, and the majority of the other

458 adjacent valleys. Key geomorphological features that are pronounced are the break of slope associated

459 with the relatively resistant Dogger and Blea Wyke sandstone, sharp scarps, and smooth convex

460 slopes found above the $320 \mathrm{~m}$ contour line. The upper part of this slope is mantled by soliflucted head

461 deposits that contain weathered rounded sandstone boulders 'ploughing boulders' (Fig. 7 Section B).

462 Erosion of weathered Whitby Mudstone from the rear scarp (e.g. Loc. 12 in Fig. 5) has deposited

463 colluvium onto the head of this slide mass, and although vegetation of the scarp slope has somewhat

464 arrested this erosion process, this area is prone to future instability due to river erosion. Advancement

465 of the conceptual ground model requires drilling rotary boreholes to $+60 \mathrm{~m}$ in the main body (Zone II)

466 and above the crown. Deeper holes would better constrain the lithostratigraphic unit thicknesses, and

467 provide samples for further materials testing.

469 6. Landslide movement history

\subsection{Geomorphological evidence}

471 There are no historic records of large-scale movements of the landslide; however, the relative sequence of movements can be inferred from interpretation of the geomorphic and geological

473 evidence. The truncation of periglacial head deposits by the main (rear) back scarp (Figs. 5 and 7B),

474 and the presence of head beneath the mudflow deposits (BH4, Appendix 1), constrain the main

475 movement event to the early-late Holocene times. Preservation of ridge and furrow plough lines in

476 Zone III (Fig. 6) suggests this area has not been active in this area in historic times. However, rotation

477 and dislocation of Whitby Mudstone from the main landslide mass on the western flank (Fig. 7

478 Section B), is evidence for a secondary phase of deep-seated movement after the main event and this 
possibly postdates some of the frontal mudflow activity in Zone III. The minor scarps and benches shown in Zone II (Fig 7 Section B) provide evidence for 'recent' to 'old' rotational slides, driven by toe erosion by Slidney Beck and this process is still intermittently 'active'. Very recent activity is limited to small-scale translational slides in weathered or disturbed mudstone on stream banks and minor rockfall from the sandstone beds exposed along main escarpment cliff and along the banks of drainage gullies (Fig. 5, Locs 4, 12 and 13).

\subsection{Sediment dating}

The frontal mudflow complex (Fig. 4, in Zone III) contains buried palaeosols which were cored and dated to help constrain the age of the latest mudflow events. Inspection of cores during logging of BH4A identified a peat deposit below a mudflow event horizon between 2.74 and $2.90 \mathrm{~m}$ b.g.l.

(Appendix 1). This soil horizon is composed of olive grey organic silt with pockets of amorphous peat containing fragments of wood and charred material; the upper boundary is sharp indicating erosion by an overriding mudflow event(s). Another horizon containing dark brown peat with scattered rootlets and wood was also proved at a similar depth in BH4, located approx $1 \mathrm{~m}$ to the west of BH4A (Fig. 5 \& Appendix 1). These soils likely preserve deposition and vegetation of shallow surface depressions on the upper surface of a mudflow.

Radiocarbon dating methods were used to determine the age of this sediment. Fragments of wood were extracted during examination using clean gloves and tools to minimise contamination. Precautions were also taken during percussive drilling to minimise hydrocarbon contamination (duck oil). The sediment samples were stored horizontally in a humidity and temperature controlled fridge at $4^{\circ} \mathrm{C}$ for c. 6 months at BGS Keyworth prior to logging and sampling. Three of the fragments of wood, extracted from various depths between 2.84 to $2.89 \mathrm{~m}$ in BH4A, were analysed for age determination using Accelerator Mass Spectrometry (AMS) techniques by Beta Analytic (Beta Nos 343215, 343216, 343217). Samples were analysed to ISO 17025 standards, and were first pre-treated using the acid/alkali/acid method. The results of the AMS analysis are shown in Table 3. 
506 Table 3. Radiocarbon-dated samples from the Mark Nab landslide mudflow cores.

\begin{tabular}{|c|c|c|c|c|c|c|c|c|}
\hline Core & Depth (m) & $\begin{array}{l}\text { OS Grid } \\
\text { reference } \\
(\mathrm{x}, \mathrm{y},)\end{array}$ & $\begin{array}{l}\text { Sample type and } \\
\text { pre-treatment }\end{array}$ & Lab. ID number & Measured Age (BP) & $13 \mathrm{C} / 12 \mathrm{C}$ o/oo & $\begin{array}{l}\text { Conventional }{ }^{14} \mathrm{C} \text { age } \\
\text { (BP) }\end{array}$ & $\begin{array}{l}2 \text { SIGMA } \\
\text { CALIBRATION }\end{array}$ \\
\hline BH4A & $2.850-2.900$ & $\begin{array}{l}471566 \\
503341\end{array}$ & $\begin{array}{l}\text { Charred material: } \\
\text { acid/alkali/acid }\end{array}$ & Beta-343217 & $2240 \pm 30$ & -23.0 & $2270 \pm 30$ & $\begin{array}{l}\mathrm{Cal} \mathrm{BC} 400 \text { to } 350(\mathrm{Cal} \\
\mathrm{BP} 2350 \text { to } 2300) / \mathrm{Cal} \\
\text { BC } 290 \text { to } 230(\mathrm{Cal} \mathrm{BP} \\
2240 \text { to } 2180) / \mathrm{Cal} \mathrm{BC} \\
220 \text { to } 210(\mathrm{Cal} \mathrm{BP} 2170 \\
\text { to } 2160)\end{array}$ \\
\hline BH4A & 2.840 & $\begin{array}{l}471566 \\
503341\end{array}$ & $\begin{array}{l}\text { Charred material: } \\
\text { acid/alkali/acid }\end{array}$ & Beta-343216 & $2340 \pm 30$ & -23.2 & $2370 \pm 30$ & $\begin{array}{l}\text { Cal BC } 510 \text { to } 390(\mathrm{Cal} \\
\text { BP } 2460 \text { to } 2340)\end{array}$ \\
\hline BH4A & 2.870 & $\begin{array}{l}471566, \\
503341\end{array}$ & $\begin{array}{l}\text { Charred material: } \\
\text { acid/alkali/acid }\end{array}$ & Beta-343215 & $2340 \pm 30$ & -26.2 & $2320 \pm 30$ & $\begin{array}{l}\text { Cal BC } 400 \text { to } 380 \text { (Cal } \\
\text { BP } 2360 \text { to } 2330 \text { ) }\end{array}$ \\
\hline
\end{tabular}

507

508 These dates constrain the latest mudflow event in BH4A to after $2270 \mathrm{yrs}$ BP. The earliest date of the buried palaeosol coincides with a period of climatic deterioration to a wetter climate, but also major woodland clearance by early Iron Age people, as indicated for example by pollen records from the nearby Fen Bogs site (Simmons et al., 1993; Innes et al., 1999). This late-Holocene erosion event corroborates other records from wetlands formed behind landslides in the North York Moors at

513 Gormire Lake, St Helena and Blakey, where a link between erosion and deforestation has been 514 suggested by Innes et al. (1999).

\section{Landslide trigger factors and mechanisms of failure}

\subsection{Slope stability models}

518 A set of slope stability models were developed to quantitatively test the conceptual ground model and 519 explore the initial landslide trigger factors and assess the current day stability state. The geotechnical 520 property values used in the stability models are provided in Table 4 . The values were estimated

521 values, based mainly on the BGS's geotechnical database for the Lias Group (Hobbs et al., 2005) and 522 the general literature (Reeves et al., 2006). A small number of geotechnical tests (ring shear and shear box) were carried out on samples of Whitby Mudstone Formation collected from the landslide deposit 
itself (shear zone exposed at head of gully near Loc 4, Fig. 5.) and other samples collected from another landslide shear zone exposed at river level at nearby East Arnecliff Wood. These data were not used directly but were used to inform an expert judgement based estimate of the residual shear strength of the Whitby Mudstone at the Nark Nab landslide site. The density and porosity data were taken mainly from the BGS's geotechnical database. Two main slope scenarios were modelled: i) a pre-failure slope, and ii) the present day 'post-failure' slope.

Table 4. Geotechnical property values used for slope stability models (after Hobbs et al., 2005;

532 Reeves et al., 2006; Hobbs and Boon, 2013). $c^{\prime}$ : effective cohesion ; $\phi$ :effective angle of internal 533 friction.

\begin{tabular}{|c|c|c|c|c|c|c|c|c|}
\hline \multirow{2}{*}{$\begin{array}{l}\text { Geological layer } \\
\text { (lithology) }\end{array}$} & \multirow{2}{*}{$\begin{array}{l}\text { Layer } \\
\text { thickness } \\
\text { (m) }\end{array}$} & \multirow{2}{*}{$\begin{array}{l}\text { Saturated density } \\
\left(\mathrm{kg} \mathrm{m}^{-3}\right)\end{array}$} & \multirow{2}{*}{$\begin{array}{l}\text { Dry density } \\
\left(\mathrm{kg} \mathrm{m}^{-3}\right)\end{array}$} & \multirow{2}{*}{$\begin{array}{l}\text { Porosity, } \mathrm{n} \\
(\%)\end{array}$} & \multicolumn{2}{|c|}{ Pre-slip 'peak' } & \multicolumn{2}{|c|}{ Post-slip 'residual' } \\
\hline & & & & & $\begin{array}{l}c^{\prime} \\
\mathrm{MPa}\end{array}$ & $\begin{array}{l}\phi \\
\text { degr. }\end{array}$ & $\begin{array}{l}c^{\prime} \\
\mathrm{MPa}\end{array}$ & $\begin{array}{l}\phi{ }^{\prime} \\
\text { (degr.) }\end{array}$ \\
\hline Saltwick Formation (Sst/Slst/Mst) & 25 & 2350 & 2200 & 0.15 & 0.20 & 25 & 0.0 & 25 \\
\hline Whitby Mudstone Formation (Mst) & 201 & 2060 & 1710 & 0.35 & 0.015 & 26 & 0.0 & 10 \\
\hline $\begin{array}{l}\text { Cleveland Ironstone Formation } \\
\text { (Slst/Mst/Irnst) }\end{array}$ & infinite & 2060 & 1710 & 0.35 & 0.5 & 30 & 0.5 & 30 \\
\hline
\end{tabular}

534

536 The model was used to perform a 'back-analysis' to investigate the sensitivity of the paraglacial

537 Jurassic Escarpment to various environmental trigger factors, including:

538 (1) Glacial buttressing and loss of that lateral support (de-buttressing)

539 (2) Presence of a pro-glacial lake

540 (3) Groundwater level rise after deglaciation 
542 The model variables chosen to represent these primary factors were: slope angle, groundwater level,

543 and surface water level, respectively. The pre-failure slope analyses used two approaches: 'finite

544 element' using FLACslope (version 7) and 'limit-equilibrium' using Galena (version 6). The results

545 from finite element modelling were, where appropriate, used to inform the geometry of the slip

546 surface defined in the limit-equilibrium model. Further details of the analyses methods and results are

547 provided in Hobbs and Boon (2013). The surface profile was based on a structural reconstruction of

548 the cross section in Fig. 6A, which assumes a $43^{\circ}$ planar slope.

\subsection{Glacial buttressing}

551

To investigate the potential effect of glacial buttressing on the sequence of slope deformation we considered two simple models:

553

i) Ice buttressed: over steepened slope, $80 \mathrm{~m}$ high, with ice buttressing up to the $270 \mathrm{~m}$ contour line.

554

ii) Non-buttressed: over steepened slope, $125 \mathrm{~m}$ high, no ice buttressing.

555

Both scenarios were modelled in FLAC using the same geological unit thicknesses (Fig 8A) and 'peak' strength properties (Table 4). The water table in model (i) was assumed to be deep, assuming no free water and deep permafrost conditions, whereas the water table in model (ii) assumes a shallow water table and re-establishment of the regional water table and potential for excess pore pressure build up in the slope.

The FLAC modelling results are shown in Fig. 8B,C. Fig. 8B shows the over steepened 'buttressed' slope is inherently unstable ( $F o S$ of 0.95$)$ and prone to failure, but with shallow movement occurring as minor shallow rotation affecting only the Whitby Mudstone and Dogger units. This result supports the idea of an initial 'upper' slope failure (as implied by 'Interpretation 1'; Fig. 6A). The results of model (ii) in Fig. 8C, shows the slope is also unstable when glacial de-buttressing has occurred, but the failure mode is significantly different from that of the buttressed slope stability model (i), with a deep-seated rotation affecting the full slope in Fig. 8C. One key limitation of this slope modelling 
method is that model (i) substitutes the ice mass for a Whitby Mudstone mass due to software

568 limitations. Therefore, model (i) is unlikely to produce a deeper basal failure mode (similar to

569 Interpretation 2 in Fig. 6). However, a deep-seated bedding-controlled failure with a basal slip surface

570 geometry which daylights within the ice mass, similar to Interpretation 2 Fig. $6 \mathrm{~A}$, is also a feasible

571 failure mechanism.

572
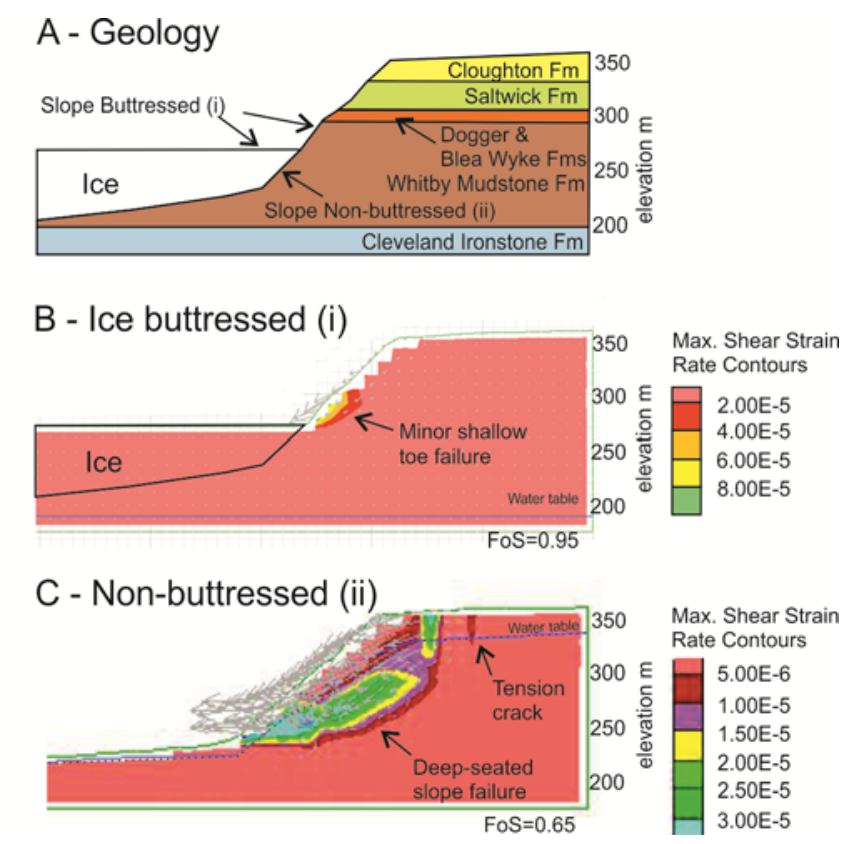

574 Fig. 8. Results of FLAC slope stability modeling. A) Geological layers. Properties given in Table 4.

575 Note: Ice mass is substituted for Whitby Mudstone Formation properties due to software limitations.

576 B) Results for a glacially buttressed slope scenario. C: Results for a glacially de-buttressed slope

577 scenario.

\subsection{Model sensitivity}

579 One assumption in the models is that the para-glacial slope was c. $43^{\circ}$. This slope angle is based on

580 cross section reconstruction and so there is a lot of uncertainty in the pre failure slope angle. To investigate the sensitivity of the stability models to this uncertainty, and to better understand the general relationship between slope angle and stability condition across the region, we modelled a range of generic Whitby Mudstone Formation slopes using FLAC. We use 'peak' strength properties 
584 (Table 4) and assume the formation is $90 \mathrm{~m}$ thick. The results are plotted in Fig. 9A, which shows that 585 the Jurassic Escarpment becomes increasingly unstable as slope angle increases. This result is not 586 surprising; however, the relationship suggests that if a $90 \mathrm{~m}$ thick Whitby Mudstone Formation slope 587 exceeds a critical angle of c. $22^{\circ}$ the failure mode is more likely to favour deep-seated rotational 588 sliding over a translation sliding mode. The slide plane exploits 'landslide prone horizons' entirely within the Whitby Mudstone Formation and the primary shear surface daylights at the base of the escarpment (in a toe failure), above the Cleveland Ironstone Formation. To validate the model result with empirical data, slope angles of failed and non-failed slopes in Great Fryup Dale were measured remotely in GeoVisionary using a slope model derived from the $0.25 \mathrm{~m}$ resolution LiDAR data (Fig. 4). Using this approach we find that deep-seated landslides tend only to be found on the Jurassic escarpment when the average slope angle exceeds c. $21^{\circ}$. This empirical method not only provides a useful 'sense check' on the assumptions made in the stability modelling, but also provides an improved understanding and a critical slope angle cut off which could be applied for regional landslide susceptibility mapping purposes.

FoS for a conceptual pre-slipped Whitby Mudstone slope (i) is 0.8 , suggesting that without additional lateral support (i.e. glacial buttressing) these slope would not have stood up on its own at c. $43^{\circ}$. Following this logic it is highly plausible that an initial 'upper' slope failure initiated in the upper part of the escapement (a 'slope failure') while the glacier was still providing some lateral support (i.e. paraglacial failure). The slope may have even started to relax due to lateral unloading during valley glaciation phases, with dilation of pre-existing discontinuities (e.g. Joints, faults, fractures) which would have increased the secondary hydraulic permeability of the rock mass. The combined effects of these geological processes would have preconditioned the slope for a further 'lower' failure as the ice mass reduced in volume. We have represented this rock mass dilation effect in our stability models by addition of a tension crack $10 \mathrm{~m}$ behind the crown. However, the presence of frozen ground under permafrost conditions could also have increased the shear strength of the near surface slope materials, delaying development of a shallower failure mechanism in favour of a deeper-seated slope failure 
which propagates beneath the frozen crust. This failure mechanism could account for the existence of

611 large intact blocks preserved in Zone II.

612 Although the pre-slip stability model (Fig. 8A) results presented thus far lend support to a deep-seated rotational mode of failure during a partial glacial de-buttressing phase, other potential trigger factors, such as the reported pro-glacial lake in Eskdale and a post glacial rise in regional groundwater levels, may also have contributed to the hillslope instability along the non-glaciated parts of the escarpment and in other regions south of the Devensian limit, such as the Cotswolds. These two additional trigger factors were investigated using modified slope stability models and the methods and results are briefly described in the following subsection.

619
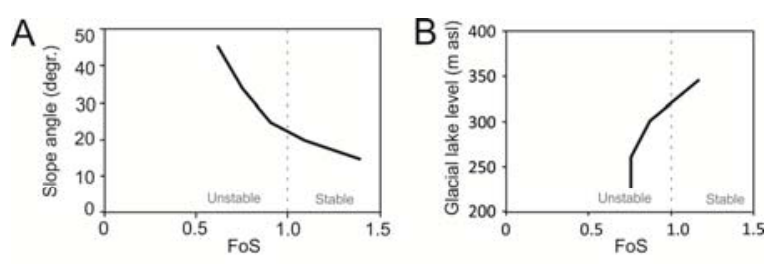

620

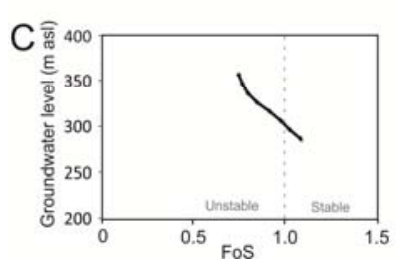

621 Fig. 9. Plots showing the results of slope stability model sensitivity analysis of key physical factors

622 for Whitby Mudstone Formation slopes: A) relationship between slope angle and $F o S$; B) glacial-lake level and $F o S$; and C) relationship between $F o S$ and regional groundwater level. (A) and (B) assume a deep-seated non-circular rotational failure mode on a $43^{\circ}$ hillslope in horizontally-bedded Whitby Mudstone Formation mudstone.

\subsection{Glacial lake drawdown scenario}

Kendall (1902) proposed the Esk valley was once flooded by a pro-glacial lake, Lake Eskdale, which reached a maximum height of $225 \mathrm{~m}$ aOD (Kendall, 1902; Radge, 1939; Gregory 1962a,b; Kent et al., 1980; Murton and Murton, 2011). If this lake really did exist, the lake water would partially filled 
631 Great Fryup Dale and the adjacent valleys. The effect of a changing water body level on the stability

632 of the pre-slip Jurassic Escarpment was modelled by varying the level of the water table in the

633 stability model.

634 The results, plotted as the relationship between lake level and stability state (FoS) in Fig. 9B, indicate 635 that a rising lake level would have promoted stability, but that a rapid lowering of the lake level, while 636 the slope is still in a saturated state, would have promoted instability.

\subsection{Groundwater rebound scenario}

639

A similar reduction in stability is also achieved by raising the regional groundwater level, so draining of a pro-glacial lake would probably not have been required to trigger the initial main failure as the slope was already likely metastable anyway. The climatic amelioration at the start of the Holocene would have seen re-establishment of the surface drainage network and a rise in regional groundwater levels. This is evidenced by formation of sapping erosion related landforms such as the Hole of Horcum which is reputed to have formed shortly after the LGM (Cooper, 2007). To test the sensitivity of an oversteepended deglaciated slope to rising groundwater levels we back-analysed a Whitby Mudstone slope using the reconstructed pre-slip hillslope geometry of $43^{\circ}$ and peak strength values (Table 4). The groundwater level was raised in increments of $10 \mathrm{~m}$ to simulate rising groundwater conditions, under long term 'drained' effective stress pore water conditions. The model results summarised in Fig. 9C indicate that a rise in groundwater level significantly reduces the stability of the Jurassic escarpment slope. The model is also very sensitive to slope angle (Fig 9Aa). The stability model results from Hobbs and Boon (2013) show that a deep-seated rotational failure mode is favoured when groundwater level rises above around $303 \mathrm{~m}$ aOD. When groundwater level reaches this elevation the sandstone cap rock (Dogger Formation) would have seemingly become fully saturated and started to behave like an aquifer by providing water into the landslide prone Whitby Mudstone Formation unit below and increased its load, hence promoting instability. 
658

659

660

661

662

663

664

665

666

667

The most feasible primary trigger mechanism for the initial Mark Nab landslide is loss of lateral support due to over steepening of the slope by glacial erosion and de-butressing, although groundwater rise likely also played a role. Subsequent increases in effective rainfall and stream downcutting and erosion likely drove secondary movements, further block disruption, and initiated subsequent first time failures at the heads of incised valleys. Seismic and rainfall triggering were also considered, but not modelled. More widely, the combined roles of (i) glacial de-buttressing, as described by McColl and Davies (2013); and (ii) bedding-controlled failure, similar to that described in SE England by Bromhead and Ibsen (2004), and (iii) regional groundwater rise, likely triggered and drove landslide activity along glaciated and non-glaciated Jurassic slopes in Britain. In the deep, supposedly non-glaciated (during the Devensian) incised moorland valleys to the south, such as Rosedale, it is possible that first-time failures occurred due to over-steepening that occurred during earlier valley glaciation, and reactivation occurred under rising groundwater level conditions, although more investigation is needed.

Reconstruction of the slope profile at Mark Nab also provides a new estimate of recession rate for the Jurassic Escarpment in glaciated valleys in Northern Britain through the Holocene; we estimate between 0.01 and $0.005 \mathrm{~m} \mathrm{yr}^{-1}$ of recession to have occurred since the LGM, mainly controlled by mass movement processes. This rate assumes the main phase of landslide-driven erosion initiated c. $13,000 \mathrm{yrs} \mathrm{BP}$, at the end of the Late Devensian, although more precise dating of the main failure would help constrain these estimates.

\subsection{Current stability state}

The residual stability of the majority of relict landslides in the UK is largely unknown, and although they are generally considered dormant or inactive (Jones and Lee, 1994), they have been known to reactivate and cause damage (e.g. Fish et al., 2006). Effective assessment of relict slopes requires appropriate site investigation and a ground model. 
We used the Galina software package to model the stability state of the 'present day' slope using the current topographic profile determined from the 5-m NextMap, and 'residual' shear strength values for the landslide-prone Whitby Mudstone Formation (Table 4). We also considered sensitivity of the model to different slip plane geometry and modelled the stability condition using the both the shallow and deep slip plane geometries proposed in 'Interpretation 1' and 'Interpretation 2' of Fig. 7 Section A, respectively.

The Sarma non-vertical (multi) slice, non-circular analyses were used for all Galena models. The 'residual' strength value $(\phi, r)$ for the Whitby Mudstone Formation was increased from the laboratory measured value of $9^{\circ}$ to $10^{\circ}$ to account for the fact that the clay is unlikely to be at fully remoulded strength at the field scale due to inclusion of lithorelicts, discontinuity roughness effects, and possible added cohesion provided by secondary crystallisation along ancient inactive shear surfaces. The results of the Interpretation 1 model (involving an 'upper' and 'lower' slip surface geometry based on Fig. 7A), indicate the 'upper' landslide mass is currently stable $(F o S=2.71)$, and the separate 'lower' slide mass of Interpretation 1 is also stable $(F o S=1.42)$. If we assume the both slip surfaces are connected and the landslide mass behaves as one coherent mass the slope is also seemingly stable $(F o S=1.85)$. There was no field-based evidence to suggest the main landslide masses are currently unstable, other than minor failures along gulley slopes, and the stability modelling strengthens the notion that the slope as globally 'dormant'. However, the stability of the 'upper' mass would decrease if the 'lower' mass were to move, as the latter provides some clear buttressing, these interdependencies highlight the dynamic nature of these landslide systems and it seems likely that complex and delicate physical feedbacks are still in operation within these relict slopes.

In terms of landslide activity state using the terminology of Jones and Lee (1994), the evidence from the dating of mudflows in Zone III suggests they are 'Dormant' rather than 'Inactive - Ancient' implying Zone III areas at this site, and similar Zone III type slopes elsewhere in the region, are most prone to reactivation by extreme environmental conditions such as increased effective rainfall. 
712 There is uncertainty in the 'current day' stability model, which relies heavily on assumptions about

713 the geometry of the slide planes(s). The slide plane geometry is more certain where there is drilling

714 and geophysics data (Zone I). There is some uncertainty in the 'post slip-residual' model input values

715 (Table 4) which were limited to lab-scale test results so these may not accurately reflect field-scale values. Although some provision was made for this, by increasing residual strength value slightly from $9^{\circ}$ to $10^{\circ}$, the material and mass strength will likely vary at the field-scale due to a variety of multi-scale effects and processes, including: variability in clay content and type, re-consolidation (Gibo et al., 2002), large-scale 3D internal friction effects between landslide blocks (Morgenstern, 1995), external friction effects along mudstone landslide boundaries (e.g. Massey et al., 2013), and secondary mineralisation increasing shear resistance (adding cohesion). Another source of error in the stability models is the accuracy of the position of the water table, and the assumption this is static. In the 'current day' slope model the water table is assumed planar with its depth informed by peizometer data from $\mathrm{BH} 2$, although this level is unlikely to be uniform across the slope, as the occurrence of springs testifies.

The pre-slide slope stability models have some major limitations, for example, the pre-slipped slope profile, groundwater levels and pre-slip slip surface geometry are estimates, constrained by limited ground monitoring data, as previously discussed. The pre-slide slope stability model is very sensitive to slope angle, as shown from the sensitivity analysis of slope angle in Fig. 9A. The geotechnical values (Table 4) are also largely estimates based on values from the literature and some limited shear strength testing from on-site and nearby site materials. Nevertheless, back-analysis using slope stability modelling techniques does offer a useful tool to test our understanding of plausible failure mechanisms in ancient landslides, and informs the current day regional hazard and sensitivity of the 
system to environmental and anthropogenic perturbations. To reduce the uncertainties in the ground model, and the stability models developed from it, deep drilling is required with groundwater monitoring, materials testing, mineralogical studies, and further geophysics (e.g. passive and active seismic).

\section{Conclusions}

A combination of geological, geomorphological, geophysical, dating, and stability modelling techniques have been applied here to reconstruct the $2 \mathrm{D}$ architecture and failure mechanism of a relict landslide on the Jurassic Escarpment in Northern England. This paper provides the basis for a preliminary ground model for the Mark Nab slope and the numerous other large, deep-seated bedrock landslides typically found across the North York Moors region. The study shows that the large slope failures are typically developed in weak mudstone lithology of the Lower Jurassic mudstones (Whitby Mudstone Formation) and the principal failure mechanism is geologically controlled by the thickness of the mudstone and the presence of bedding controlled failures along 'slide-prone horizons'.

Geomorphological evidence and new radiocarbon dating of sediment provides new understanding of the landslide movement history, and this knowledge helps inform expert based landslide hazard assessment in the region. The study includes the first application of the ERT geophysical technique to image a deep-seated landslide in Jurassic rocks in the Cleveland Basin. The combined approach, where ERT is calibrated with borehole data and detailed geological mapping, proved crucial in the assessment of the landslide deposit volume, 3D internal architecture and depth of principal slip surfaces. Static slope stability modelling (non-dynamic) suggests that the slope most likely initially failed in response to glacial over steepening and de-buttressing. However, groundwater rise is also a contributing factor to instability in the region, and may have triggered and reactivated the large landslides in the adjacent non-glaciated valleys, such as Rosedale. Slope reconstruction provides new recession rate estimations for the North Yorkshire Jurassic Escarpment. Although currently inactive and dormant, the frontal mudflow complexe has at Mark Nab has been active within the last 2700 
years BP, and this and similar slopes are moderately prone to becoming unstable again under future wetter climates. These mudflow systems can be easily recognised and mapped using modern high resolution LiDAR data to improve landslide hazard maps and models. Importantly, this slope and other similar ones are also vulnerable to renewed instability caused by adverse anthropogenic activity, drainage alteration or major civil engineering works. The combined geomorphological and geophysical approach described through this case study will be of interest to hazard geologists and engineering geologists working on landslide problems in similar geological settings, including other UK Jurassic escarpments, and overseas. The paper is also relevant to those involved with or planning landslide hazard and risk studies in high latitude regions currently undergoing active de-glaciation.

\section{Acknowledgements}

The authors would like to thank landowners Mr Stephen Smith, Mr Robert Smith, and Lord Burridge for allowing us to access to the field site. Thanks to BGS Staff, particularly Vanessa Banks, Anthony Cooper, and David Schofield for helpful reviews of the early manuscript. We would also like to express our appreciation to the BGS Dando drilling team: Stephen Thorpe, Carl Horabin, Helen Smith, Dave Morgan, 'Gill', and Andrew Naylor. Henry Holbrook and Simon Ward are acknowledged for cartography, and Hannah Jordan, Mark Barron, Andy Howard, Chris Vane, and Helen Reeves are thanked for discussions in the field and lab. Greg Botha and another anonymous reviewer are thanked for their constructive feedback on the paper. The work was funded by the BGS/NERC Shallow Geohazards and Risks project. The BGS authors publish with the permission of the Executive Director of the British Geological Survey (Natural Environmental Research Council).

\section{References}

Anon. 1972. The preparation of maps and plans in terms of engineering geology. Quarterly Journal of Engineering Geology 5, 297-367. 
801

Anon, 1995. The description and classification of weathered rocks for engineering purposes. Engineering Group of the Geological Society Working Party report. Quarterly Journal of Engineering Geology, Vol. 28, 207242.2)

British Standards Institution. 1999. BSI 5930:1999 Code of Practice for Site Investigations, incorporating Amendments 1 and 2. British Standards Institution, London.

Barron, A. J. M., Lott, G.K., Riding, J.B. 2012. Stratigraphical framework for the Middle Jurassic strata of Great Britain and the adjoining continental shelf. British Geological Survey Research Report RR/11/06. 187pp.

Bromhead, E.N., Ibsen, M.-L. 2004. Bedding-contolled coastal landslides in Southeast Britain between Axmouth and the Thames Estuary. Landslides. 1:131-141.

Chambers, J. E., Ogilvy, R. D., Kuras, O ., Cripps, J. C. \& Meldrum, P. I. 2002. 3D electrical imaging of known targets at a controlled environmental test site. Environmental Geology 41, 690-704.

Chambers, J. E., Wilkinson, P. B., Kuras, O., Ford, J. R., Gunn, D. A., Meldrum, P. I., Pennington, C. V. L., Weller, A. L., Hobbs, P. R. N. \& Ogilvy, R. D. 2011. Three-dimensional geophysical anatomy of an active landslide in Lias Group mudrocks, Cleveland Basin, UK. Geomorphology 125, 472-484.

Chiverrell, R.C., Thomas, G.S.P. 2010. Extent and timing of the Last Glacial Maximum (LGM) in Britain and Ireland: a review. J. Quaternary Sci. 25, 535-549.

Cooper, R.G. 2007. Mass Movements in Great Britian. Geological Conservation Review Series, No. 33. Joint Nature Conservation Committee, Peterborough.

Cox. B. M., Sumbler. M. G., Ivimey-Cook. H.C. 1999. A formational framework for the Lower Jurassic of England and Wales (onshore area). British Geological Survey Research Report RR/99/01. British Geological Survey. 
819 Cruden, D. M., Varnes, D.J., 1996. Landslide types and processes. In Special Report 247: Landslides:

820 Investigation and Mitigation, Transportation Research Board, Washington D.C.

821

822

823

824

825

826

827

828

829

830

831

832

833

834

835

836

837

838

839

840

841

842

843

844

Fell, R., Corominas, J., Bonnard, C., Cascini, L., Leroi, E. and Savage, W. Z. 2008. Guidelines for landslide susceptibility, hazard and risk zoning for land use planning. Engineering Geology 102. pp85-98

Fish, P. R., Moore, R. \& Carey, J.M. 2006. Landslide geomorphology of Cayton Bay, North Yorkshire, UK. Proceedings of the Yorkshire Geological Society 56, 5-14.

Fookes, P. G. 1997. Geology for Engineers: the Geological Model, Prediction and Performance. Quarterly Journal of Engineering Geology and Hydrogeology 30, 293-424.

Fox - Strangways, C.F., Reid, C., \& Barrow, G., 1885. The Geology of Eskdale, Rosedale \& etc. Explaination of quarter-sheet 96 N.E. New Series Sheet 43. Memoirs of the Geological Survey. 56pp.

Gibo, S., Egashira, K., Ohtsubo, M., Nakamura, S. 2002. Strength recovery from residual state in reactivated landslides. Geotechnique. 52, No. 9, 683-686.

Gregory, K, J. 1962a. Contributions to the geomorphology of the North York Moors. (Unpublished PhD thesis).

Gregory, K.J. 1962b. The deglaciation of Eastern Eskdale, Yorkshire. 1962. Proceedings of the Yorkshire Geological Society 33, 363-380.

Griffiths. J. S. (eds). 2002. Mapping in Engineering Geology. GSL Key Issues in Earth Sciences. Geological Society of London. pp294. 

Internal Report No. IR/05/008.

848

Hobbs, P.R.N., Boon, D.P. 2013. Great Fryup landslide: slope stability analyses. British Geological Survey Internal Report IR/13/002. British Geological Survey, Nottingham.

851

Holliday, D. W., Howard, A. S., Pattison. 1992. Sheet 43 Egton (Eskdale and Farndale) solid and drift edition. British Geological Survey. HMSO.

854

Howard, A.S. 1985. Lithostraigraphy of the Staithes Sandstone and Cleveland Ironstone formations (Lower Jurassic) of north-east Yorkshire. Proceedings of the Yorkshire Geological Society. Vol. 45, 261-275.

857 England. Field Guide, Quaternary Research Association, London. p21-34.

860 environments in the Vale of Mowbray, North Yorkshire, UK: evidence from palynology. Proceedings of the Geologists' Association 120, 199-208.

864

Johnson. R., Fish, P. 2012. Reactivation of the coastal landslide system at Cayton Bay, North Yorkshire, UK.

Jones, D.K.C., Lee, E.M. 1994. Landslides and landsliding in Great Britain. HMSO, London. 
Kendall, P.F.,1902. A system of glacial lakes in the Cleveland Hills. Quarterly Journal of the Geological Society

Kent, P., Wilson, V., Gaunt, G.D., 1980. British Regional Geology Eastern England from the Tees to The Wash.

McColl, S.T. and Davies, T.H.R. 2013. Large ice-contact slope movements: glacial buttressing, deformation and 
901

902

903

904

905

906

907

908

909

910

911

912

913

914

915

916

917

918

919

920

921

922

923

924

925

926

927

928

Morgenstern, N.R., 1995. Keynote paper: the role of analysis in the evaluation of slope stability. In: Bell (Ed.), Landslides. Balkema, Rotterdam.

Murton, D.K. and Murton, J.B. 2011. Middle and Late Pleistocene glacial lakes of lowland Britain and the southern North Sea Basin. Quaternary International 260, 115-142.

Olayinka, A. I. \& Yaramanci, U. 2000. Assessment of the reliability of 2D inversion of apparent resistivity data. Geophysical Prospecting 48, 293-316.

Powell, J.H ., Cooper, A. H., Benfield, A C. 1992. Geology of the country around Thirsk. Memoir of the British Geological Survey, Sheet 52 (England and Wales).

Powell, J.H. 2010. Jurassic sedimentation in the Cleveland Basin: a review. Proceedings of the Yorkshire Geological Society 58, 21-72.

Radge, G.W. 1939. The glaciation of North Cleveland. Proceedings of the Yorkshire Geological Survey 24, 190-205.

Reeves, G.M., Sims, I., Cripps, J.C. (Eds.), 2006. Clay Materials Used in Construction. The Geological Society, Engineering Geology Special Publication. No. 21.

Schuster, R. L., and Highland. L. M. 2001. Socioeconomic and environmental impacts of landslides in the Western Hemisphere. U.S. Dept. of the Interior, U.S. Geological Survey Open File Report 01-0276.

Senior, J. and Rose, J. 1994. The Jurassic, Tertiary and Quaternary around Great Ayton and Roseberry Topping, Cleveland Hills, 11. In: Scrutton, C. (ed.) Yorkshire Rocks and Landscape - A Field Guide. Yorkshire Geological Society. 
929 Simmons, I. G., Atherden, M.A., Cloutman, E.W., Cundill, P.R., Innes, J.B., Jones, R.L. 1993. Prehistoric

930 environments. In: Spratt, D.A. (ed.) Prehistoric and Roman Archaeology of North-East Yorkshire. Council for

931 British Archaeology Research Report 87, BAR British Series 104, Council for British Archaeology, London, $932 \quad 15-50$.

933

934 Waltham, A., Forster, A. 1999. Man as geological agent. GEOLOGY TODAY, November-December 1999 vol 935 217. Blackwell Science Ltd.

936

937 Young, T.P. 1994. The Blea Wyke Sandstone Formation (Jurassic, Toarcian) of Rosedale, North Yorkshire, UK.

938 Proceedings of the Yorkshire Geological Society 50, 129-142. 